\title{
The lowermost Pleistocene rodent and soricid (Mammalia) fauna from Beremend 14 locality (South Hungary) and its biostratigraphical and palaeoecological implications
}

\author{
Piroska Pazonyi ${ }^{1}$, Lukács Mészáros ${ }^{2}$, János Hí R ${ }^{3} \&$ Zoltán Szentesi ${ }^{4}$ \\ ${ }^{1} M T A-M T M-E L T E$ Research Group for Palaeontology, \\ H-1083 Budapest, Ludovika tér 2, Hungary.E-mail:pinety@gmail.com \\ ${ }^{2}$ Department of Palaeontology, Eötvös Loránd University, \\ H-1117 Budapest,Pázmány Péter sétány 1/C, Hungary.E-mail: lgy.meszaros@gmail.com \\ ${ }^{3}$ Municipal Museum, H-3060 Pásztó, Múzeum tér 5, Hungary.E-mail: hirjanos@gmail.com \\ ${ }^{4}$ Department of Palaeontology and Geology, Hungarian Natural History Museum, \\ H-1083 Budapest, Ludovika tér 2, Hungary.E-mail: crocutaster@gmail.com
}

\begin{abstract}
The limestone quarry of Beremend yielded the classical Late Pliocene and Early Pleistocene vertebrate faunas studied for more than a century. The Beremend 14 site was discovered in the 1970s by Dénes Jánossy. Twenty four small mammal species and twenty seven elements of herpetofauna were identified from its rich vertebrate material. Based on the taxonomical study of small mammals, we suppose that the stratigraphic position of the site is the Early Pleistocene MN 17 Zone. The palaeoecological analysis of the fauna suggests warm, dry climate and open, probably wooded grassland vegetation surroundings of the site with smaller open water surface. With 47 figures and 14 tables.
\end{abstract}

Key words - biostratigraphy, Early Pleistocene, Hungary, palaeoecology, small mammals

\section{INTRODUCTION}

The Szölö Hill of Beremend is located approximately $9 \mathrm{~km}$ south from the range of Villány Hills and municipality Villány, in South Hungary. Altitude of the flat, loess covered, limestone hill is $174 \mathrm{~m}$. The limestone quarry of Beremend yielded the classical vertebrate faunas studied for more than a century by Petényi, Kretzoi, Krolopp, and Jánossy (see in JáNOssY 1986). Numerous karst cavities containing Pliocene-Pleistocene mammalian faunas were explored from the Lower Cretaceous limestone. According to Kretzoi (1969) and Kretzor \& PÉCSI (1982) the sites of Beremend represent Late Pliocene Beremendian Biochronological Phase. However, according to Krolopp (1990), this phase overlaps with the beginning of the Early Pleistocene (Early Villanyian). 
Bone remains were first presented from Beremend by PETÉNYI (1864). Since then, 26 sites have been described from the quarry (KRETzor 1956; JÁnossY 1986; Kordos 1991; Pongrácz 1999; CsászÁr \& Kordos 2004) (Fig. 1). Beremend 14 site discovered in the 1970s, is northeast from the Beremend Crystal Cave. Unfortunately, we have not got other information from this site, because it has been destroyed, probably it was a karst fissure with red clay infill-

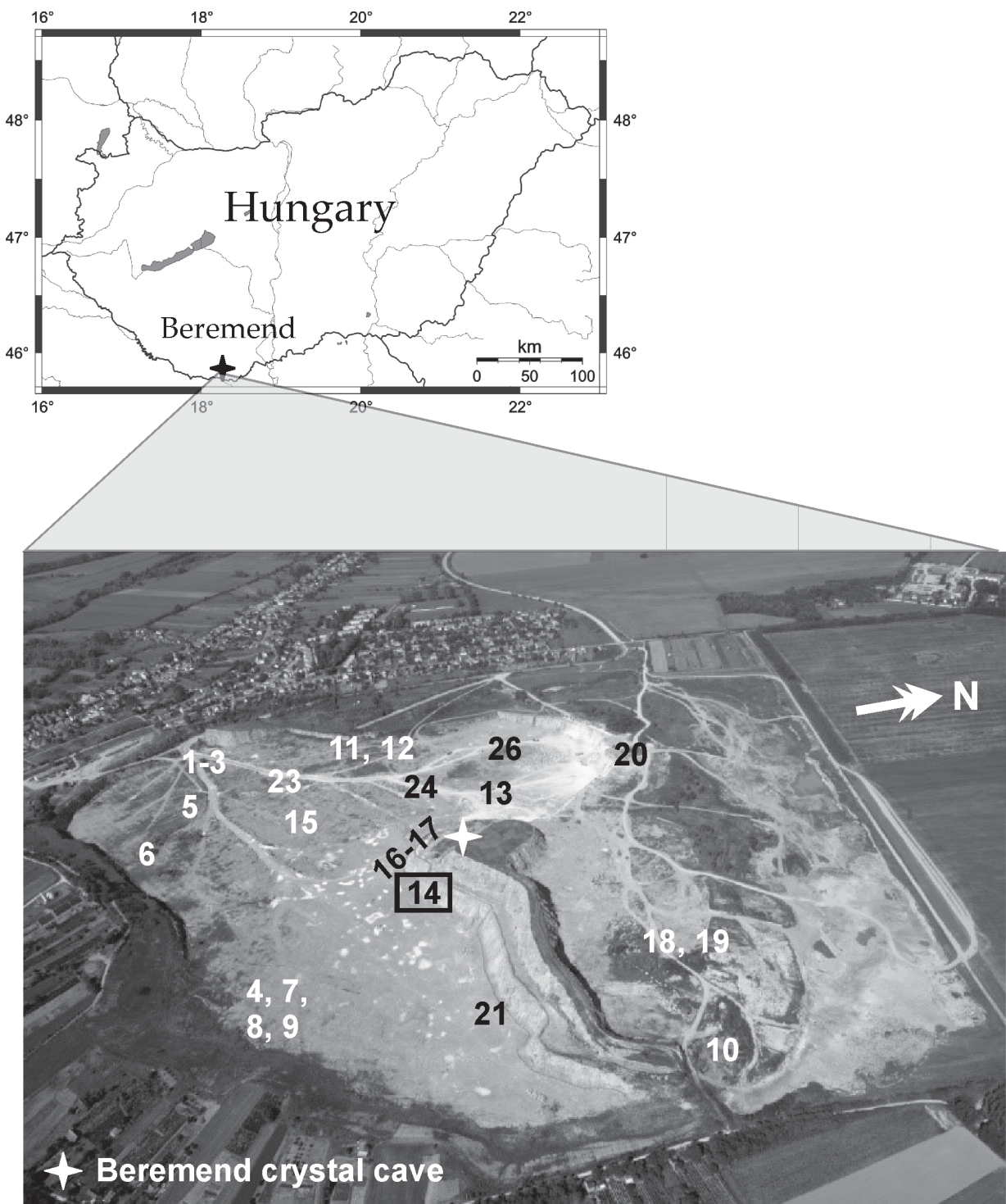

Fig. 1. Location of the Beremend 14 site (Villány Hills, South Hungary) 
ing. This paper presents the soricid and rodent fauna, and its biostratigraphical as well as palaeoecological implications.

The presented fossils were unearthed from previously screen-washed deposits, which were probably collected by Dénes Jánossy in 1977. The unprocessed, scattered material is stored in the Department of Palaeontology and Geology of the Hungarian Natural History Museum, Budapest. Due to sorting and processing of this material (VER 2016.3568., 2016.3569., 2016.3570., 2016.3571., 2016.3572., 2016.3573., 2016.3574.), rich fauna was found. We have identified the fossils as follows:

Triturus cristatus (Laurenti, 1768)

Lissotriton vulgaris (Linnaeus, 1758)

Salamandridae indet.

Bombina variegata Linnaeus, 1758

Pelobates fuscus (Laurenti, 1768)

Bufo bufo (Linnaeus, 1758)

Bufotes viridis Laurenti, 1768

Bufo sp.

Hyla arborea (Linnaeus, 1758)

Rana temporaria Linnaeus, 1758

Rana sp.

Anura indet.

Lacertidae indet.

Anguidae indet.

Sauria indet.

Sauria indet. coprolite

Hierophis viridiflavus Lacépède, 1789

Hierophis gemonensis (Laurenti, 1768)

Coronella austriaca Laurenti, 1768

Elaphe quatuorlineata Szyndlar, 1984

Elaphe paralongissima (Lacépède, 1789)

Zamenis longissimus Laurenti, 1768

Natrix natrix (Linnaeus, 1758)

Natrix tessellata (Laurenti, 1768)

Natrix sp.

Telescopus fallax (Fleischmann, 1831)

Colubridae indet.

Carnivora indet.

Chiroptera indet.

Erinaceomorpha indet.

Talpidae indet. 
Crocidura kornfeldi Kormos, 1934

Sorex minutus Linnaeus, 1766

Sorex runtonensis Hinton, 1911

Sorex (Drepanosorex) savini Hinton, 1911

Beremendia fissidens (Petényi, 1864)

Petenyia hungarica Kormos, 1934

Asoriculus gibberodon (Petényi, 1864)

Spermophilus primigenius (Kormos, 1934)

Glis minor Kowalski, 1956

Estramomys aff. simplex Jánossy, 1969

Sicista praeloriger Kormos, 1930

Prospalax cf. priscus (Nehring, 1897)

Allocricetus ehiki Schaub, 1930

Cricetus nanus (Schaub, 1930)

Dolomys milleri Nehring, 1898

Villanyia exilis Kretzoi, 1956

Mimomys reidi Hinton, 1910

Mimomys pusillus (Méhely, 1914)

Pitymimomys pitymyoides (Jánossy et van der Meulen, 1975)

Borsodia newtoni (F. Major, 1902)

Allophaiomys deucalion Kretzoi, 1969

Lagurodon arankae (Kretzoi, 1954)

Apodemus dominans Kretzoi, 1959

Micromys praeminutus Kretzoi, 1959

\section{SYSTEMATIC PALAEONTOLOGY}

Phylum Vertebrata Linnaeus, 1758

Classis Mammalia Linnaeus, 1758

Order Eulipotyphla Waddell et al., 1999

Family Soricidae Fischer von Waldheim, 1817

Eight Soricidae species were determined in the Beremend 14 fossil assemblage (Table 1). Crocidura kornfeldi Kormos, 1934 is ranged to subfamily Crocidurinae, while other six forms: Sorex minutus Linnaeus, 1766; Sorex (Drepanosorex) savini Hinton, 1911; Sorex runtonensis Hinton, 1911; Beremendia fissidens (Petényi, 1864); Petenyia hungarica Kormos, 1934, and Asoriculus gibberodon (Petényi, 1864) belong to subfamily Soricinae. One form could not be exactly determined, because it shows both Crocidurinae and Soricinae characters, so it was defined as Soricidae gen. et sp. indet. 
Table 1. The specific remains of the Beremend 14 Soricidae fauna

\begin{tabular}{lcccccc}
\hline Species & \multicolumn{2}{c}{ Remain } & \multicolumn{2}{c}{ Teeth } & \multicolumn{2}{c}{ MNI } \\
\cline { 2 - 7 } & $\mathrm{n}$ & $\%$ & $\mathrm{n}$ & $\%$ & $\mathrm{n}$ & $\%$ \\
\hline Crocidura kornfeldi & 101 & 17.06 & 158 & 30.56 & 13 & 21.67 \\
Sorex minutus & 9 & 1.52 & 7 & 1.35 & 3 & 5.00 \\
Sorex savini & 9 & 1.52 & 11 & 2.13 & 4 & 6.67 \\
Sorex runtonensis & 15 & 2.53 & 26 & 5.03 & 5 & 8.33 \\
Beremendia fissidens & 435 & 73.48 & 292 & 56.48 & 28 & 46.67 \\
Petenyia hungarica & 7 & 1.18 & 10 & 1.93 & 2 & 3.33 \\
Asoriculus gibberodon & 12 & 2.03 & 10 & 1.93 & 4 & 6.67 \\
Soricidae gen. et sp. indet. & 4 & 0.68 & 3 & 0.58 & 1 & 1.67 \\
\hline Total & 592 & 100.00 & 517 & 100.00 & 60 & 100.00 \\
\hline
\end{tabular}

Abbreviations used in the Soricidae descriptions: $\mathrm{I}=$ incisor, $\mathrm{A}=$ antemolar, $\mathrm{P}=$ premolar, $\mathrm{M}=$ molar, $\mathrm{M}^{\mathrm{x}}=$ upper tooth, $\mathrm{M}_{\mathrm{x}}=$ lower tooth, $\mathrm{L}=$ length, $\mathrm{W}=$ width, $\mathrm{H}=$ height, $\mathrm{BL}=$ buccal length, $\mathrm{LL}=$ lingual length, $\mathrm{AW}=$ anterior width, $\mathrm{PW}=$ posterior width, $\mathrm{n}=$ number of specimens, $\min .=$ minimum, $\max .=$ maximum, sd. = standard deviation, $\mathrm{MNI}=$ minimum number of individuals. Calculation of MNI is based on the number of identical, ipsilateral teeth. Morphological terms are used after REUMER (1984). Measurements are given in mm.

Remarks - In the relative groups of the shrews several Erinaceomorpha and Talpidae species with more than 250 specimens occurred in the Beremend 14 sample, but they are not discussed in this paper.

Subfamily Crocidurinae Milne-Edwards, 1874

Genus Crocidura Wagler, 1832

Crocidura kornfeldi Kormos, 1934

(Fig. 2)

Material - 14 left mandible fragments with $3 \mathrm{I}_{1}, 4 \mathrm{~A}_{1}, 9 \mathrm{~A}_{2}, 10 \mathrm{M}_{1}, 10 \mathrm{M}_{2}, 5$ $\mathrm{M}_{3} ; 12$ right mandible fragments with $1 \mathrm{I}_{1}, 3 \mathrm{~A}_{1}, 4 \mathrm{~A}_{2}, 5 \mathrm{M}_{1}, 4 \mathrm{M}_{2}, 1 \mathrm{M}_{3} ; 1$ skull fragment with left $A^{1}, A^{3}, M^{1}-M^{3}$ and right $A^{1}-A^{3}, P^{4}, M^{1}-M^{2} ; 15$ left maxillary fragments with $2 \mathrm{I}^{1}, 1 \mathrm{~A}^{1}, 1 \mathrm{~A}^{2}, 1 \mathrm{~A}^{3}, 5 \mathrm{P}^{4}, 9 \mathrm{M}^{1}, 7 \mathrm{M}^{2}$; 8 right maxillary fragments with $1 \mathrm{I}^{1}, 3 \mathrm{~A}^{1}, 3 \mathrm{~A}^{2}, 2 \mathrm{~A}^{3}, 4 \mathrm{P}^{4}, 5 \mathrm{M}^{1}, 4 \mathrm{M}^{2}$; Isolated teeth: 7 left and 12 right $\mathrm{I}_{1}, 2$ left and 5 right $M_{1}$ or $M_{2}, 2$ right $M_{3}, 5$ left and 5 right $I^{1}, 1$ left and 1 right $A^{1}, 2$ right $\mathrm{P}^{4}, 4$ left and 2 right $\mathrm{M}^{1}, 1$ left and 2 right $\mathrm{M}^{2}$.

Measurements - Table 2.

Description - Dental formula is $143 / 123$. The dental elements are not pigmented. The coronoid process is blunt and low. The coronoid spicule is small, 
Table 2. Measurements of Crocidura kornfeldi teeth (Beremend 14)

\begin{tabular}{lcccccc}
\hline & & $\mathrm{n}$ & min. & mean & max. & sd. \\
\hline $\mathrm{M}^{1}$ & $\mathrm{LL}$ & 10 & 1.28 & 1.42 & 4.48 & 0.06 \\
& $\mathrm{BL}$ & 10 & 1.46 & 1.53 & 1.60 & 0.04 \\
& $\mathrm{AW}$ & 10 & 1.65 & 1.74 & 1.80 & 0.05 \\
& $\mathrm{PW}$ & 10 & 1.92 & 2.05 & 2.18 & 0.08 \\
\hline $\mathrm{M}^{2}$ & $\mathrm{LL}$ & 10 & 1.12 & 1.21 & 1.28 & 0.05 \\
& $\mathrm{BL}$ & 10 & 1.16 & 1.24 & 1.32 & 0.05 \\
& $\mathrm{AW}$ & 10 & 1.88 & 1.96 & 2.04 & 0.05 \\
& $\mathrm{PW}$ & 10 & 1.56 & 1.62 & 1.76 & 0.07 \\
\hline $\mathrm{M}_{1}$ & $\mathrm{~L}$ & 10 & 1.40 & 1.58 & 1.72 & 0.10 \\
& $\mathrm{~W}$ & 10 & 0.98 & 1.04 & 1.18 & 0.10 \\
\hline $\mathrm{M}_{2}$ & $\mathrm{~L}$ & 10 & 1.38 & 1.52 & 1.64 & 0.10 \\
& $\mathrm{~W}$ & 10 & 0.86 & 0.92 & 0.96 & 0.04 \\
\hline
\end{tabular}

situated high and indistinct. The external temporal fossa is long, narrow and indistinct. The internal temporal fossa is reaching to halfway up the coronoid process, and a subfossa is present above it. $\mathrm{I}^{1}$ apex is pointed and the talon also has a little, sharp cone. The cingulum along the posterior buccal margin is narrow but well-pronounced, usually it is undulate. The first upper antemolar is elongated, the two posterior ones are considerably smaller. $\mathrm{A}^{3}$ is somewhat smaller than $\mathrm{A}^{2}$. The parastyle of $\mathrm{P}^{4}$ is protruding and separated from the paracone by a deep valley. The protocone is small. A small hypocone is visible on the cingulumlike ridge running along the lingual margin of the tooth. The posterior margins of $\mathrm{P}^{4}$ and $\mathrm{M}^{1}$ are much concave. Both of the upper molars are relatively broad and short. The $\mathrm{M}^{1} \mathrm{AW}$ is far smaller than the $\mathrm{PW}$. The shape of $\mathrm{M}^{2}$ is trapezoidal, its anterior part is far wider than the posterior one. The parastyle on $\mathrm{M}^{2}$ is long and curved, while the metastyle is short and straight. $\mathrm{M}^{3}$ protocone, paracone, and hypocone are about equal in size. $\mathrm{I}_{1}$ is slightly bicuspulate. The buccal cingulum is narrow but pronounced. $\mathrm{A}_{1}$ is anteroposteriorly quite elongate, but low, $A_{2}$ is much higher. $M_{1}-M_{2}$ buccal cingula are narrow but well-pronounced. It is undulate in all specimens, but it is less undulate on $M_{2}$ than on $M_{1} \cdot M_{3}$ talonid is reduced to a single cuspid.

Remarks - There are two similar Crocidura species reported from the Early Pleistocene of Europe: C. kornfeldi Kormos, 1934 and C. obtusa Kretzoi, 1938. BotKa \& MÉszáros (2015) distinguished these two forms by the characteristics of the mandible. Based on the shape of the coronoid process and the indistinct coronoid spicule we ranged the Beremend 14 Crocidura remains to $C$. kornfeldi. 
Subfamily Soricinae Fischer von Waldheim, 1817

Tribe Soricini Fischer von Waldheim, 1817

Genus Sorex Linnaeus, 1758

Sorex minutus Linnaeus, 1766

(Fig. 3)

Material - 1 incomplete right mandible with $A_{2}$ fragment and $M_{1}-M_{2}\left(M_{1}: L\right.$ $\left.=1.24, \mathrm{~W}=0.66 ; \mathrm{M}_{2}: \mathrm{L}=1.01, \mathrm{~W}=0.60\right) ; 2$ left and 2 right edentulous mandible fragments; 1 left $\mathrm{I}^{1}$ fragment; 1 right $\mathrm{A}^{1} ; 1$ right $\mathrm{M}^{1}(\mathrm{LL}=1.28, \mathrm{BL}=1.28, \mathrm{AW}=$ $1.36, \mathrm{PW}=1.52) ; 1$ right $\mathrm{M}^{2}(\mathrm{LL}=1.12, \mathrm{BL}=1.14, \mathrm{AW}=1.40, \mathrm{PW}=1.29)$.

Description - Very small-sized Sorex form with light orange pigmentation on the tip of the teeth. $\mathrm{M}^{1}-\mathrm{M}^{2}$ are subquadrate, with specifically concave posterior emargination. The buccal cingulum is well-developed but narrow, and usually undulated on the lower molars. The anterior edge of the coronoid process is concave, the apex bends slightly towards anterior direction. The external temporal fossa is developed as a longitudinal groove. The coronoid spicule is present. The internal temporal fossa is high and triangular, continuing to the tip of the coronoid process.

\section{Sorex runtonensis Hinton, 1911}

(Fig. 4)

Material - 1 left corpus mandibulae with condyle; 1 left mandible fragment with $\mathrm{I}_{1}$ and $\mathrm{A}_{2}-\mathrm{M}_{3}\left(\mathrm{M}_{1}: \mathrm{L}=1.34, \mathrm{~W}=0.76 ; \mathrm{M}_{2}: \mathrm{L}=1.16, \mathrm{~W}=0.68\right) ; 1$ left mandible fragment with $\mathrm{M}_{1}-\mathrm{M}_{3}\left(\mathrm{M}_{1}: \mathrm{L}=1.50, \mathrm{~W}=0.80 ; \mathrm{M}_{2}: \mathrm{L}=1.30, \mathrm{~W}=0.78\right) ; 1$ left mandible fragment with $\mathrm{M}_{1}-\mathrm{M}_{2}\left(\mathrm{M}_{1}: \mathrm{L}=1.56, \mathrm{~W}=0.84 ; \mathrm{M}_{2}: \mathrm{L}=1.32, \mathrm{~W}=0.80\right)$; 1 incomplete left mandible with $I_{1}$ fragment and $A_{2}-M_{2}\left(M_{1}: L=1.48, W=0.80\right.$; $\left.\mathrm{M}_{2}: \mathrm{L}=1.32, \mathrm{~W}=0.76\right) ; 1$ left mandible fragment with $\mathrm{A}_{2}-\mathrm{M}_{2}\left(\mathrm{M}_{1}: \mathrm{L}=1.54, \mathrm{~W}=\right.$ $\left.0.84 ; \mathrm{M}_{2}: \mathrm{L}=1.36, \mathrm{~W}=0.76\right) ; 1$ right $\mathrm{I}_{1}(\mathrm{~L}=3.04, \mathrm{H}=0.78) ; 2$ left $\mathrm{P}^{4}(\mathrm{LL}=1.08$, $\mathrm{BL}=1.40, \mathrm{~W}=1.68 ; \mathrm{LL}=0.96, \mathrm{BL}=1.56, \mathrm{~W}=1.62) ; 1$ left $\mathrm{M}^{1}(\mathrm{LL}=1.45, \mathrm{BL}=$ $1.44, \mathrm{AW}=1.56, \mathrm{PW}=1.73) ; 3$ right $\mathrm{M}^{1}(\mathrm{LL}=1.32, \mathrm{BL}=1.33, \mathrm{AW}=1.44, \mathrm{PW}$ $=1.52 ; \mathrm{LL}=1.44, \mathrm{BL}=1.44, \mathrm{AW}=1.48, \mathrm{PW}=1.64 ; \mathrm{LL}=1.40, \mathrm{BL}=1.36, \mathrm{AW}=$ $1.52, \mathrm{PW}=1.66) ; 1$ right $\mathrm{M}^{1}$ and 1 right $\mathrm{M}^{2}$ fragments.

Description - The teeth are pigmented with orange to red colour. The pentagonal $\mathrm{P}^{4}$ has a well-developed parastyle and protocone. The protocone is placed in the central part of the anterior side of the tooth. The subquadrate $\mathrm{M}^{1}$ has well-developed hypocone and indistinct metaloph. The posterior emargination of $\mathrm{P}^{4}$ and $\mathrm{M}^{1}$ is moderately developed. The coronoid process is tall and leans forwards; its anterior margin is concave. The deep external temporal fossa of coronoid process runs along the posterior border of the process. The coronoid spicule is well-developed. The internal temporal fossa is high and triangular. $I_{1}$ is tricuspulate. $M_{1}$ is bigger than 

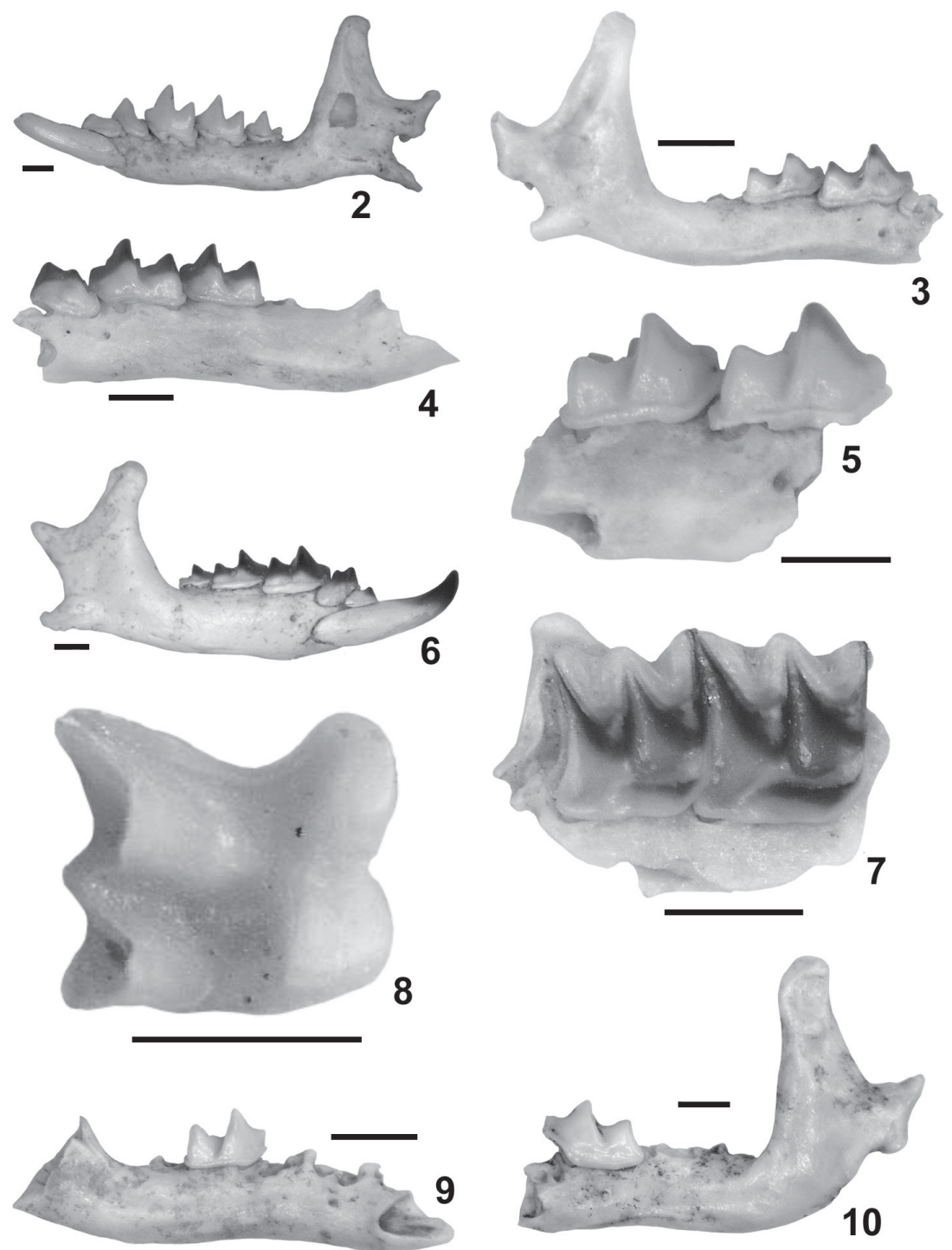

Fig. 2. Crocidura kornfeldi Kormos, 1934; complete left mandible, buccal view (VER 2016.3572.1.). - Fig. 3. Sorex minutus Linnaeus, 1766; incomplete right mandible with $A_{2}$ fragment and $M_{1}-M_{2}$, buccal view (VER 2016.3572.2.). - Fig. 4. Sorex runtonensis Hinton, 1911; left mandible fragment with $A_{2}$ and $M_{1}-M_{2}$, buccal view (VER 2016.3572.3.). - Fig. 5. Sorex (Drepanosorex) savini Hinton, 1911; right mandible fragment with $\mathrm{M}_{1}-\mathrm{M}_{2}$, buccal view (VER 2016.3572.4.). - Fig. 6. Beremendia fissidens (Petényi, 1864); complete right mandible, buccal view (VER 2016.3572.5.). - Fig. 7. Petenyia hungarica Kormos, 1934; right maxillary fragment with $\mathrm{M}_{1}-\mathrm{M}_{2}$, occlusal view (VER 2016.3572.6.). - Figs 8-9. Asoriculus gibberodon (Petényi, 1864). - 8. Left $\mathrm{M}_{1}$, occlusal view (VER 2016.3572.7.). - 9. Right mandible fragment with $\mathrm{M}_{2}$, buccal view (VER 2016.3572.8.). - Fig. 10. Soricidae gen et sp. indet.; left mandible fragment with $M_{1}$, buccal view (VER 2016.3572.9.). Scale bars $=1 \mathrm{~mm}$ 
$M_{2} . M_{1}$ buccal cingulum is undulate while it is straight in $M_{2}$ and $M_{3}$. The molars are characterized by high entoconid crests. $\mathrm{M}_{3}$ is unreduced with basined talonid.

Sorex (Drepanosorex) savini Hinton, 1911

(Fig. 5)

Material - 2 right mandible fragment with $\mathrm{M}_{1}-\mathrm{M}_{2}\left(\mathrm{M}_{1}: \mathrm{L}=1.50, \mathrm{~W}=0.88\right.$; $\left.\mathrm{M}_{2}: \mathrm{L}=1.44, \mathrm{~W}=0.80 ; \mathrm{M}_{1}: \mathrm{L}=1.52, \mathrm{~W}=0.94 ; \mathrm{M}_{2}: \mathrm{L}=1.48, \mathrm{~W}=0.84\right) ; 1$ left $\mathrm{I}_{1}$ $(\mathrm{L}=3.20, \mathrm{H}=0.82) ; 2$ right $\mathrm{M}_{1}(\mathrm{~L}=1.60, \mathrm{~W}=0.92 ; \mathrm{L}=1.58, \mathrm{~W}=0.86) ; 1$ left $\mathrm{M}_{2}$ $(\mathrm{L}=1.44, \mathrm{~W}=0.88) ; 1$ right $\mathrm{M}_{2}(\mathrm{~L}=1.32, \mathrm{~W}=0.68) ; 1$ left $\mathrm{M}^{1}$ fragment; 1 right $\mathrm{M}^{1}(\mathrm{LL}=1.44, \mathrm{BL}=1.48, \mathrm{AW}=1.64, \mathrm{PW}=1.72)$.

Description - Large-sized shrew with light-orange pigmentation on the teeth. $M^{1}$ is square, its metaloph is present. $I_{1}$ is tricuspulate. $M_{1}$ is bigger and more elongated than $M_{2}$. Buccal cingulum is not undulate on the lower molars. The entoconid crests are high on $\mathrm{M}_{1}-\mathrm{M}_{2}$.

Remarks - Two Sorex (Drepanosorex) species are known from the European Lower Pleistocene. Sorex savini was described by Hinton (1911) from West Runton, England. In the Betfia (also known as Püspökfürdő, Romania) material Kormos (1930) distinguished another species for a similar form as $S$. margaritodon. Thence several shrew remains were mentioned from different localities as $S$. (D.) margaritodon or $S$. (D.) savini. The taxonomical details are shown in another article of the current issue of the present journal (BOTKA \& MÉszÁros 2016). After those studies, Sorex (Drepanosorex) margaritodon Kormos, 1930 is regarded here as a synonym of Sorex (Drepanosorex) savini Hinton, 1911, so the Beremend 14 specimens are systematized as $S$. (D.) savini, which is the earlier name, so the valid one.

Tribe Beremendiini Reumer, 1984

Genus Beremendia Kormos, 1934

Beremendia fissidens (Petényi, 1864)

(Fig. 6)

Material - 14 left more or less complete mandibles (containing also coronoid process and condyle), with $7 \mathrm{I}_{1}, 7 \mathrm{~A}_{1}, 8 \mathrm{~A}_{2}, 11 \mathrm{M}_{1}, 12 \mathrm{M}_{2}, 9 \mathrm{M}_{3}$; 14 right one, with $8 \mathrm{I}_{1}, 4 \mathrm{~A}_{1}, 7 \mathrm{~A}_{2}, 13 \mathrm{M}_{1}, 12 \mathrm{M}_{2}, 10 \mathrm{M}_{3}$; 11 left mandible fragments with $2 \mathrm{I}_{1}, 2 \mathrm{~A}, 2$ $A_{2}, 2 M_{1}, 3 M_{2} ; 10$ left mandible fragments with $3 I_{1}, 1 A_{1}, 2 A_{2}, 7 M_{1}, 5 M_{2}, 1 M_{3}$; 3 left more or less complete skulls; left teeth: $3 \mathrm{I}^{1}, 3 \mathrm{~A}^{1}, 3 \mathrm{~A}^{2}, 2 \mathrm{~A}^{3}, 3 \mathrm{P}^{4}, 3 \mathrm{M}^{1}, 2 \mathrm{M}^{2}$, $1 \mathrm{M}^{3}$; right teeth: $3 \mathrm{I}^{1}, 1 \mathrm{~A}^{1}, 1 \mathrm{~A}^{2}, 2 \mathrm{~A}^{3}, 1 \mathrm{~A}^{4}, 3 \mathrm{P}^{4}, 3 \mathrm{M}^{1}, 3 \mathrm{M}^{2}, 2 \mathrm{M}^{3}$; 8 left maxillary fragments with $6 \mathrm{P}^{4}, 4 \mathrm{M}^{1}, 4 \mathrm{M}^{2}, 2 \mathrm{M}^{3} ; 12$ right maxillary fragments with $1 \mathrm{I}^{1}, 2 \mathrm{~A}^{1}$, $3 \mathrm{P}^{4}, 8 \mathrm{M}^{1}, 4 \mathrm{M}^{2}, 1 \mathrm{M}^{3}$; isolated teeth: 19 left and 14 right $\mathrm{I}_{1}, 13$ left and 8 right $\mathrm{M}_{1}$, 6 left and 7 right $M_{2}, 7$ left and 6 right $M_{3}, 15$ left and 14 right $I^{1}, 10$ left and 8 right $\mathrm{P}^{4}, 5$ left and 4 right $\mathrm{M}^{1}, 9$ left and 6 right $\mathrm{M}^{2}, 1$ left and 2 right $\mathrm{M}^{3}, 48$ antemolars. 
Measurements - Table 3.

Description - Dental formula is $153 / 123$. The teeth are intensively stained dark red. The $\mathrm{I}^{1}$ is fissident with a bifid apex. Four upper antemolars are present. $\mathrm{A}^{1}$ and $\mathrm{A}^{2}$ are of about equal size, $\mathrm{A}^{3}$ is smaller and $\mathrm{A}^{4}$ is even smaller, it is quite reduced. The posterior emargination is moderate on the $\mathrm{P}^{4}, \mathrm{M}^{1}$ and $\mathrm{M}^{2}$. The lingual part of the $\mathrm{P}^{4}$ crown is very low. The occlusal outline of the $\mathrm{M}^{1}$ is square with rounded corners, $\mathrm{M}_{2}$ is trapezoidal. The $\mathrm{M}^{3}$ is relatively small and triangular. The $I_{1}$ is grooved, acuspulate, the apex curves upwards. The $A_{1}$ is unicuspid, the $A_{2}$ is bicuspid. The $M_{1}$ and $M_{2}$ trigonid basins are deep and broad, entoconid crests are present. The $\mathrm{M}_{3}$ is reduced but its talonid is basined. The mandibular body is robust, strongly built, slightly leans laterally. The ascending ramus is anteroposteriorly broad and leans strongly medially. The coronoid process is narrow, short, stout and leans anteriorly in lateral view. The coronoid spicule is thin, poorly developed and nearly vertical. The condyloid process is characteristic. The upper articular facet is narrow and cylinder-shaped. The interarticular area is broad. The lower facet leans strongly anteriorly and it is not visible in buccal view. The angular process is very short. The internal temporal fossa is small, deep and pocketed, its shape is often round.

Remarks - There are two Beremendia species known from the European fossil assemblages. According to BоткA \& MÉszÁros (2015) the larger B. fissidens and the smaller $B$. minor are well distinguished by the size of the upper and the lower molars. On the basis of these measurements the Beremend 14 form seems to belong to the bigger species, so it was determined as B. fissidens (see Table 2 and BotKa \& MÉszÁros 2015, Tables 1-2).

Table 3. Measurements of Beremendia fissidens teeth (Beremend 14)

\begin{tabular}{lcccccc}
\hline & & $\mathrm{n}$ & min. & mean & max. & sd. \\
\hline $\mathrm{M}^{1}$ & $\mathrm{LL}$ & 4 & 2.42 & 2.52 & 2.62 & 0.09 \\
& $\mathrm{BL}$ & 4 & 2.48 & 2.64 & 2.76 & 0.12 \\
& $\mathrm{AW}$ & 4 & 2.60 & 2.68 & 2.88 & 0.13 \\
& $\mathrm{PW}$ & 4 & 2.76 & 2.83 & 2.92 & 0.08 \\
\hline $\mathrm{M}^{2}$ & $\mathrm{LL}$ & 4 & 1.88 & 2.03 & 2.20 & 0.14 \\
& $\mathrm{BL}$ & 4 & 1.96 & 2.11 & 2.16 & 0.09 \\
& $\mathrm{AW}$ & 4 & 2.69 & 2.74 & 2.84 & 0.07 \\
& $\mathrm{PW}$ & 4 & 2.00 & 2.27 & 2.36 & 0.18 \\
\hline $\mathrm{M}_{1}$ & $\mathrm{~L}$ & 7 & 2.80 & 2.85 & 3.00 & 0.08 \\
& $\mathrm{~W}$ & 7 & 1.60 & 1.67 & 1.72 & 0.04 \\
\hline $\mathrm{M}_{2}$ & $\mathrm{~L}$ & 7 & 2.26 & 2.34 & 2.40 & 0.06 \\
& $\mathrm{~W}$ & 7 & 1.36 & 1.44 & 1.56 & 0.06 \\
\hline
\end{tabular}


Genus Petenyia Kormos, 1934

Petenyia hungarica Kormos, 1934

(Fig. 7)

Material - 1 left mandible fragment with $\mathrm{M}_{2}-\mathrm{M}_{3}\left(\mathrm{M}_{2}: \mathrm{L}=1.24, \mathrm{~W}=0.84\right.$; $\left.M_{3}: L=1.04, W=0.60\right) ; 1$ left mandible fragment with $M_{3}(L=1.14, W=0.64)$; 1 right mandible fragment with $\mathrm{M}_{1}(\mathrm{~L}=1.39, \mathrm{~W}=0.80) ; 1$ left $\mathrm{M}_{1}(\mathrm{~L}=1.36, \mathrm{~W}=$ $0.80)$; 1 left maxillary fragment with $\mathrm{P}^{4}$ and broken $\mathrm{M}^{1}(\mathrm{LL}=0.84, \mathrm{BL}=1.48, \mathrm{~W}$ $=1.40) ; 1$ right maxillary fragment with $\mathrm{M}^{1}-\mathrm{M}^{2}\left(\mathrm{M}^{1}: \mathrm{LL}=1.40, \mathrm{BL}=1.44, \mathrm{AW}\right.$ $\left.=1.41, \mathrm{PW}=1.49 ; \mathrm{M}^{2}: \mathrm{LL}=1.24, \mathrm{BL}=1.16, \mathrm{AW}=1.49, \mathrm{PW}=1.36\right) ; 1$ right $\mathrm{M}^{1}$ fragment.

Description - The teeth have dark red (sometimes nearly black) pigmentation. $\mathrm{P}^{4}, \mathrm{M}^{1}$ and $\mathrm{M}^{2}$ have nearly straight posterior margin. $\mathrm{P}^{4}$ is triangular, its parastyle is well-developed and as a rule, connected to the paracone by a high parastylar crest. Hardly any posterior emargination is present on $\mathrm{M}^{1}-\mathrm{M}^{2}$. Paracone and metacone are much better developed than the protocone, the hypocone is not developed. Protocone and hypocone are separated. In occlusal view the lower molars are relatively wide and short. The entoconid crest is high. The wide re-entrant valley opens low, directly above the broad buccal cingulum. $M_{3}$ has a well-developed buccal cingulum, its talonid is reduced to a single hypoconid. The tip of the coronoid process of the mandible is broad, slightly divergent with a strongly undulating outline. The posterior margin is straight. The coronoid spicule is very large and strongly pronounced; it divides the external temporal fossa into two almost equal parts. The internal temporal fossa is high and triangular; it extends to the tip of the coronoid.

Tribe Neomyini Matschie, 1909

Genus Asoriculus Kretzoi, 1959

Asoriculus gibberodon (Petényi, 1864)

(Figs 8-9)

Material - 1 left mandible fragment with $\mathrm{M}_{1}-\mathrm{M}_{3}\left(\mathrm{M}_{1}: \mathrm{L}=1.54, \mathrm{~W}=0.81\right.$; $\left.\mathrm{M}_{2}: \mathrm{L}=1.34, \mathrm{~W}=0.76 ; \mathrm{M}_{3}: \mathrm{L}=1.06, \mathrm{~W}=0.60\right) ; 1$ left mandible fragment with $\mathrm{M}_{2}(\mathrm{~L}=1.32, \mathrm{~W}=0.76) ; 1$ right mandible fragment with $\mathrm{M}_{2}(\mathrm{~L}=1.32, \mathrm{~W}=0.80)$; 1 left and 3 right edentulous mandible fragments; 1 left $\mathrm{M}^{1}(\mathrm{LL}=1.40, \mathrm{BL}=1.36$, $\mathrm{AW}=1.52, \mathrm{PW}=1.60) ; 1$ right $\mathrm{I}_{1}\left(\mathrm{I}_{1}: \mathrm{L}=3.04, \mathrm{H}=0.76\right) ; 1$ left $\mathrm{M}_{1}(\mathrm{~L}=1.42, \mathrm{~W}$ $=0.76) ; 1$ fragmentary left $\mathrm{I}^{1} ; 1$ fragmentary right $\mathrm{M}^{2}$.

Description - Pigmentation is hardly-visible: only the very tips of some teeth have a light orange colour. $\mathrm{I}^{1}$ is fissident. $\mathrm{M}^{1}$ protocone and hypocone are separated by a wide valley, the metastyle protrudes. The anterior margin bends beside 
the protocone. The lower incisor is short and bicuspulate. $M_{1}-M_{2}$ cingula are developed on both lingual and buccal sides, the buccal one is slightly undulate, particularly in $M_{1}$. The buccal re-entrant valley opens directly above the cingulum. The lingual cingulum in $\mathrm{M}_{3}$ is weak but well-visible; the talonid is not reduced but basined. The anterior margin of the coronoid process is usually slightly concave. The internal temporal fossa is relatively small and narrow. The upper condylar facet is narrow, long and cylinder-shaped. The lower facet is strongly elongated lingually and pointing downwards. The interarticular area is notched lingually and hence quite narrow and elongate.

Soricidae gen. et sp. indet.

(Fig. 10)

Material - 1 left mandible fragment with $\mathrm{M}_{1}(\mathrm{~L}=1.76, \mathrm{~W}=0.84) ; 1$ edentulous right mandible fragment; 1 left $\mathrm{I}^{1}(\mathrm{~L}=1.92, \mathrm{H}=1.40) ; 1$ right $\mathrm{I}^{1}(\mathrm{~L}=1.84$, $\mathrm{H}=0.36)$.

Description - Medium-sized Soricidae form. The coronoid process of the mandible is Neomys-like: the external temporal fossa is divided by a strong coronoid spicule. Otherwise, this species is different from Neomini shrews in its unpigmented teeth and Crocidura-like condyle. The $\mathrm{M}_{1}$ buccal cingulum is as weak as at crocidurines, but - opposite of them - it is not undulated. Upper incisors are not fissident, they are very similar to $C$. kornfeldi $\mathrm{I}^{1}$ yielded by this site, but they are somewhat bigger than the Crocidura teeth.

\section{Order Rodentia Bowdich, 1821}

Seventeen rodents were determined in the Beremend 14 fossil assemblage, which can be classified into 7 families (Sciuridae, Gliridae, Eomyidae, Dipodidae, Spalacidae, Cricetidae and Muridae) (Table 4). Most of the species (mainly voles) belong to family Cricetidae, whereas the other families include only 1-2 species.

Family Sciuridae Gray, 1821

Genus Spermophilus Cuvier, 1825

Spermophilus primigenius (Kormos, 1934)

(Figs 11-12)

Material - Isolated teeth: 1 right $\mathrm{M}_{2} ; 1$ right $\mathrm{M}_{3} ; 1$ left $\mathrm{M}_{3} ; 2$ left $\mathrm{P}^{4} ; 1$ left $\mathrm{M}^{2}$; 2 right $\mathrm{M}^{2}$.

Description - The premolar is relatively small, front is narrower than rear (like Sciurus) and consisting of four cusps. On the labial side it is protoconid and 
Table 4. Rodent remains (Beremend 14)

\begin{tabular}{lcccc}
\hline \multirow{2}{*}{ Species } & \multicolumn{2}{c}{ Remain } & \multicolumn{3}{c}{ MNI } \\
\cline { 2 - 5 } & $\mathrm{n}$ & 1.04 & 2 & $\%$ \\
\hline Spermophilus primigenius & 8 & 0.39 & 1 & 0.63 \\
Glis minor & 3 & 0.26 & 1 & 0.31 \\
Estramomys aff. simplex & 2 & 0.26 & 1 & 0.31 \\
Sicista praeloriger & 2 & 0.78 & 2 & 0.63 \\
Prospalax cf. priscus & 6 & 7.13 & 13 & 4.08 \\
Allocricetus ehiki & 55 & 21.14 & 45 & 14.11 \\
Cricetus nanus & 163 & 0.13 & 1 & 0.31 \\
Dolomys milleri & 1 & 0.13 & 1 & 0.31 \\
Villanyia exilis & 1 & 16.86 & 65 & 20.38 \\
Mimomys reidi & 130 & 9.86 & 30 & 9.40 \\
Mimomys pusillus & 76 & 3.63 & 11 & 3.45 \\
Pitymimomys pitymyoides & 28 & 16.34 & 63 & 19.75 \\
Borsodia newtoni & 126 & 0.52 & 2 & 0.63 \\
Allophaiomys deucalion & 4 & 17.38 & 71 & 22.26 \\
Lagurodon arankae & 134 & 1.69 & 4 & 1.25 \\
Apodemus dominans & 13 & 2.46 & 6 & 1.88 \\
Micromys praeminutus & 19 & 100.00 & 319 & 100.00 \\
\hline Total & 771 & & &
\end{tabular}

hypoconid, on the lingual side is metaconid and entoconid. The anterior incisal tip is the longest. Between this and the protoconid a slight trace of the anterior inner cusp (paraconid) can be seen. A tiny accessory cusp is observed between metaconid and entoconid. The molars are large and broad, $M_{1}$ and $M_{2}$ are rhombic and consisting of the above-mentioned four main elements. The paraconid is weakly indicated on both teeth, between the meta- and entoconid, on the other hand, there are two clearly perceptible intermediate cusps. On the last molar $\left(\mathrm{M}_{3}\right)$, only one can be observed, but it is more developed. The premolar has two roots in all cases, whereas the molars have four roots.

Family Gliridae Muirhead, 1819

Genus Glis Birsson, 1762

Glis minor Kowalski, 1956

(Figs 13-14)

Material - Isolated teeth: 1 left $\mathrm{P}_{4} ; 1$ left $\mathrm{M}_{1}(\mathrm{~L}=1.63, \mathrm{~W}=1.63) ; 1$ right $\mathrm{M}^{1}$ $(\mathrm{L}=1.66, \mathrm{~W}=1.73)$. 
Description $-\boldsymbol{M}^{1}$ : The tooth has rounded square shape and seven ridges. The first and third main ridges (anteroloph and protoloph) are isolated; there is a small, isolated ridge (anterior extra ridge) between the latter two. The fourth ridge is isolated (anterior centraloph), whereas the fifth and seventh ridges (metaloph and posteroloph) are joined on the palatinal side. Between the latter two ridges, there is a small, isolated ridge (posterior extra ridge).

$\boldsymbol{P}_{4}$ : Triangular tooth, with five ridges. The first and the second ridges (anterolophid and metalophid) are joined on both sides. The third ridge (mesolophid) is isolated, whereas the fourth and fifth ridges (posterior extra ridge and posterolophid) are joined on the labial side.

$\boldsymbol{M}_{1}$ : Anteriorly elongated, narrowed tooth, with seven ridges. The first, second and third ridges (anterolophid, anterior extra ridge and metalophid) are joined on the labial side. The fourth ridge (centralophid) is short and isolated. The fifth, sixth and seventh ridges (mesolophid, posterior extra ridge, and posterolophid) are joined on the labial side.

Family Eomyidae Winge, 1887

Genus Estramomys Jánossy, 1969

Estramomys aff. simplex Jánossy, 1969

(Fig. 15)

Material - Isolated teeth: 1 right $\mathrm{M}_{1}(\mathrm{~L}=0.93, \mathrm{~W}=0.96) ; 1$ left $\mathrm{M}_{2}(\mathrm{~L}=0.8$, $\mathrm{W}=1.00)$.

Description - Roundish, lengthwise slightly compressed, brachyodont tooth with four roots. The paraconid and the protoconid-metaconid folds are in contact with each other on the occlusal surface.

Family Dipodidae Fischer von Waldheim, 1817

Genus Sicista Gray, 1827

Sicista praeloriger Kormos, 1930

(Fig. 16)

Material - Isolated teeth: 1 right $\mathrm{M}_{1}(\mathrm{~L}=1.20, \mathrm{~W}=0.93) ; 1$ left $\mathrm{M}_{3}$.

Description - The molar is two-rooted. The occlusal outline is rounded. The protoconid and the hypoconid are the highest cusps. The anteroconid, metaconid and entoconid are also well-developed. The mesolophid is low but clearly visible. The posterolophid is low and tenuous. The entoconid exhibits two spurs near the base, both directed away from the hypolophulid, one pointing to the mesolophid, and the other to the posterolophid. 
Family Spalacidae Gray, 1821

Genus Prospalax Méhely, 1908

Prospalax cf. priscus (Nehring, 1897)

(Figs 17-18)

Material - Isolated teeth: 1 left $\mathrm{M}_{1} ; 2$ left $\mathrm{M}_{2} ; 1$ right $\mathrm{M}_{2} ; 1$ right $\mathrm{M}_{3} ; 1 \mathrm{M}^{\mathrm{x}}$

Description - Cylindrical, hypsodont molars with two roots. Both in the lingual and labial sides there are enamel folds on the occlusal surface.

Family Cricetidae Fischer von Waldheim, 1817

Subfamily Cricetinae Fischer von Waldheim, 1817

The method of taking measurements of the hamster teeth is after DAAMS \& Freudenthal (1988, Fig. 1). Morphological nomenclature is after DaAms \& FREUdenthal (1988, Fig. 2), some special morphological elements are after CunncA-Bescos (2003, Fig. 1). Abbreviations: L = maximal antero-posterior length of the occlusal surface, $\mathrm{W}=$ maximal linguo-labial width of the occlusal surface. Measurements are given in $\mathrm{mm}$.

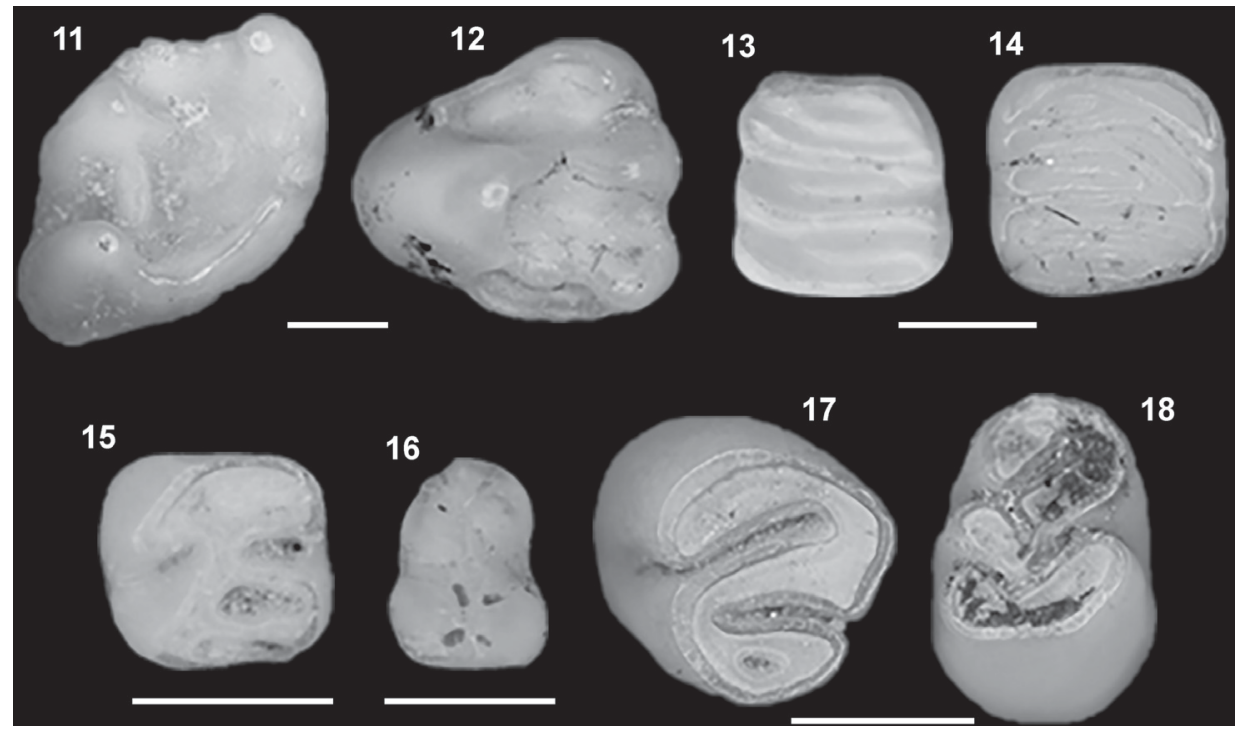

Figs 11-12. Spermophilus primigenius (Kormos, 1934). - 11. Left M (VER 2016.3573.1.). - 12. Left $M^{2}$ (VER 2016.3573.2.). - Figs 13-14. Glis minor Kowalski, 1956. - 13. Left $M_{1}$ (VER 2016.3573.3.). - 14. Right $M^{1}$ (VER 2016.3573.4.). - Fig. 15. Estramomys aff. simplex Jánossy, 1969; right $M_{1}$ (VER 2016.3573.5.). - Fig. 16. Sicista praeloriger Kormos, 1930; right $M_{1}$ (VER 2016.3573.6.). - Figs 17-18. Prospalax cf. priscus (Nehring, 1897). - 17. Right $M_{3}$ (VER 2016.3573.7.). - 18. $M^{x}$ (VER 2016.3573.8.). All occlusal views, scale bars $=1 \mathrm{~mm}$ 
Genus Allocricetus Schaub, 1930

Allocricetus ehiki Schaub, 1930

(Figs 19-24)

Material - 55 molars.

Measurements - Table 5.

Description - The molars show the general characters of the modern hamsters: the cones/ conids are definitely higher than the lophs/lophids.

$\boldsymbol{M}^{1}$ : Anterostyle is found in 4/11. Parastyle is not developed as cuspula, only cingulum is found. Protolophule 1 is developed in $8 / 11$. Short remnant mesoloph is rare: $1 / 11$. Entostyle is completely missing. It has three or four roots.

$\boldsymbol{M}^{2}$ : It has rectangular outline. The labial anteroloph is slightly longer and stronger than the lingual one. Protolophule 1 is constant. Remnant mesoloph is completely missing. It has four roots.

$\boldsymbol{M}^{3}$ : It has subtriangular outline. The posterior portion (hypocone, metacone) is narrower than the anterior one (protocone, paracone). The labial anteroloph is definitely better developed than the lingual one. Protolophule 1 is constant. In the centre of the occlusal surface central ring and remnant mesoloph are missing. It has three roots.

$M_{1}$ : Mesial surface is smooth and concave without anterostylid. Anteroconid consists of two equally developed cuspulas. The anterolophulid connects the labial anteroconid cuspula and the protoconid. Mesoconid and mesolophid are not developed. It has two roots.

$\boldsymbol{M}_{2}$ : It has rectangular outline. Lingual anterolophulid is missing (4/13), short (6/13), or middle developed (3/13). Mesolophid is rare (3/13). It is short, and reaches the posterior basis of the metaconid. Mesoconid is not developed. It has two roots.

$\boldsymbol{M}_{3}$ : It has subtriangular outline, the entoconid is reduced. Lingual anterolophid is missing (4/7) or short (3/7). Mesolophid is missing (3/7), or short $(4 / 7)$. It does not reach the posterior surface of the metaconid $(2 / 7)$, or reaches the posterior surface of the metaconid (2/7). Central ring is missing. It has two roots.

Remarks - Some plesiomorph characters (remnant mesolophs/mesolophids, undivided or 3-parted anteroconids) of the A. ehiki populations of Villány 3 and Osztramos 3 (Hír 1993) are not found among the molars of Beremend 14.

Allocricetus cf. ehiki or other large-sized Allocricetus species first appeared in the Late Miocene of Anatolia and Greece: Allocricetus aylasevimae, Çorakyerler, Turkey (MN 10-11) by ÜNAY et al. (2006); Allocricetus sp., Kavurca, Turkey (MN 13) by Rummel (1998); Allocricetus cf. ehiki, Maramena, Greece (MN 13) by DAXNER-Höck (1995). 
19

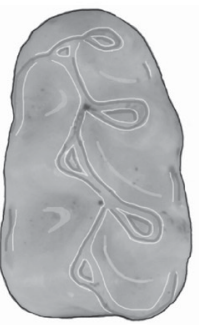

22

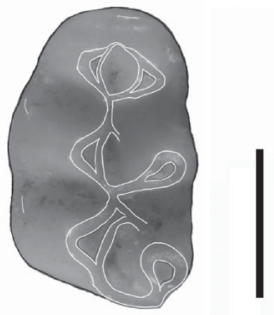

20

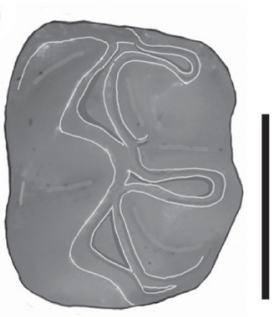

23

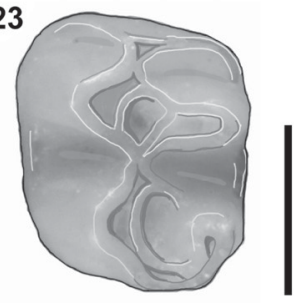

21

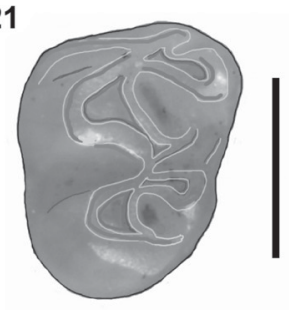

24

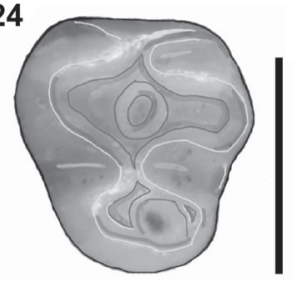

Figs 19-24. Allocricetus ehiki Schaub, 1930. - 19. Left $M_{1}$ (VER 2016.3574.1.). - 20. Left $M_{2}$ (VER 2016.3574.2.). - 21. Right $M_{3}$ (reversed) (VER 2016.3574.3.). - 22. Left $M^{1}$ (VER 2016.3574.4.). 23. Left $\mathrm{M}^{2}$ (VER 2016.3574.5.). - 24. Right $\mathrm{M}^{3}$ (reversed) (VER 2016.3574.6.). Scale bars $=1 \mathrm{~mm}$

In the Carpathian Basin this species appeared in Villány 3 and occurred up to the Middle Pleistocene. Last occurrence was found in the level 8 in the sequence of Tarkő (HÍr 1997).

Table 5. Dimensions of Allocricetus ehiki molars (Beremend 14)

\begin{tabular}{lcccccc}
\hline & & $\mathrm{n}$ & min. & mean & max. & sd. \\
\hline $\mathrm{M}^{1}$ & $\mathrm{~L}$ & 11 & 2.00 & 2.12 & 2.28 & 0.10 \\
& $\mathrm{~W}$ & 11 & 1.23 & 1.33 & 1.50 & 0.10 \\
$\mathrm{M}^{2}$ & $\mathrm{~L}$ & 10 & 1.55 & 1.69 & 1.78 & 0.10 \\
& $\mathrm{~W}$ & 10 & 1.20 & 1.41 & 1.55 & 0.12 \\
$\mathrm{M}^{3}$ & $\mathrm{~L}$ & 1 & & 1.25 & & \\
& $\mathrm{~W}$ & 1 & & 1.15 & & \\
\hline $\mathrm{M}_{1}$ & $\mathrm{~L}$ & 13 & 1.83 & 2.01 & 2.15 & 0.10 \\
& $\mathrm{~W}$ & 13 & 1.08 & 1.22 & 1.30 & 0.08 \\
$\mathrm{M}_{2}$ & $\mathrm{~L}$ & 13 & 1.50 & 1.61 & 1.83 & 0.10 \\
& $\mathrm{~W}$ & 13 & 1.20 & 1.28 & 1.38 & 0.06 \\
$\mathrm{M}_{3}$ & $\mathrm{~L}$ & 7 & 1.40 & 1.48 & 1.55 & 0.07 \\
& $\mathrm{~W}$ & 7 & 1.13 & 1.19 & 1.25 & 0.06 \\
\hline
\end{tabular}




\section{Cricetus nanus (Schaub, 1930)}

(Figs 25-30)

Material - 8 maxillae with complete tooth rows, 21 maxillae with incomplete tooth rows, 10 mandibulae with complete tooth rows, 13 mandibulae with incomplete tooth rows, $24 \mathrm{M}^{1}, 24 \mathrm{M}^{2}, 23 \mathrm{M}^{3}, 18 \mathrm{M}_{1}, 10 \mathrm{M}_{2}, 12 \mathrm{M}_{3}$.

Measurements - Tables 6 and 7.

Description $-\boldsymbol{M}^{1}$ : The mesial surface is smooth, anterostyle is rare: $7 / 45$. The relatively wide anterocone consists of two equally developed cones, which are as well-developed as the other main cones of $\mathrm{M}^{1}$ : proto-, para-, hypo- and metacones. Parastyle is not developed as cuspula, only low developed cingulum is found. Protolophule 1 is nearly constant: $41 / 45$. Short remnant mesoloph is found only in $1 / 45$, which is developed on the anterior surface of the metacone. There are four roots and one tiny root under the paracone.

$\boldsymbol{M}^{2}$ : It shows rectangular outline. The labial anteroloph is slightly stronger than the lingual one. Protolophule 1 is constant. Short remnant mesoloph is rare: $7 / 44$, which is developed on the anterior surface of the metacone. It has four roots.

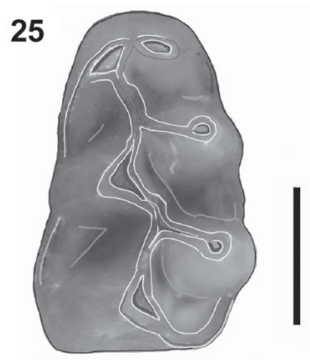

26

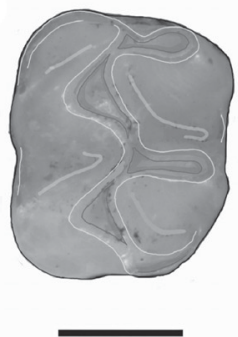

28

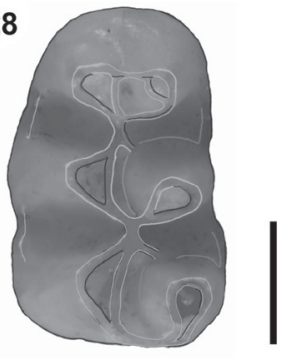

29

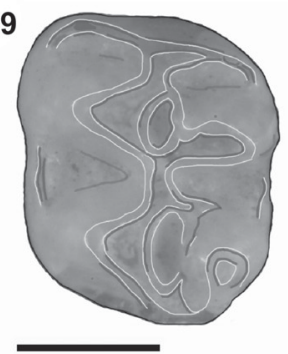

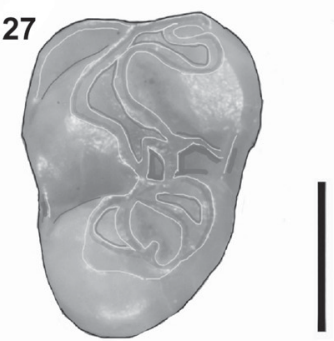

30

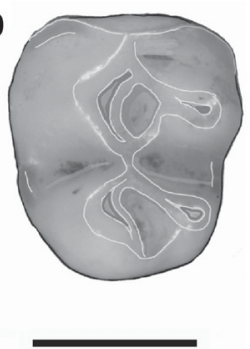

Figs 25-30. Cricetus nanus (Schaub, 1930). - 25. Left $M_{1}$ (VER 2016.3574.7.). - 26. Left $M_{2}$ (VER 2016.3574.8.). - 27. Left $M_{3}$ (VER 2016.3574.9.). - 28. Left $M^{1}$ (VER 2016.3574.10.). - 29. Left $M^{2}$ (VER 2016.3574.11.). - 30. Left $\mathrm{M}^{3}$ (VER 2016.3574.12.). Scale bars $=1 \mathrm{~mm}$ 
Table 6. Length of Cricetus nanus upper and lower tooth rows (Beremend 14)

\begin{tabular}{lccccc}
\hline C. nanus upper tooth rows & $\mathrm{n}$ & min. & mean & max. & sd. \\
$\mathrm{L} \mathrm{M}^{1}-\mathrm{M}^{2}-\mathrm{M}^{3}$ & 8 & 5.6 & 5.85 & 6.15 & 0.16 \\
\hline C. nanus lower tooth rows & $\mathrm{n}$ & min. & mean & max. & $\mathrm{sd}$. \\
$\mathrm{L} \mathrm{M}^{1}-\mathrm{M}^{2}-\mathrm{M}^{3}$ & 10 & 5.05 & 5.84 & 6.05 & 0.30 \\
\hline
\end{tabular}

$M^{3}$ : It shows subtriangular outline, the hypocone and the metacone are reduced. Some morphological elements defined by Hí (1998, fig. 28) are rare: central ring: 4/44, remnant mesoloph: $8 / 44$. There are three roots.

$M_{1}$ : It has elongated trapezoidal outline. The anteroconid region is narrower than the width across the hypoconid and the entoconid. The anteroconid consists of two equally developed cuspulas. Those are smaller than the other main cusps (proto-, meta-, hypo- and entoconid) of the $\mathrm{M}_{1}$. The anterolophulid connects the labial cuspula of the anteroconid and the protoconid. Y-like anterolophulid (which has two, equally developed anterior branches running to the two cuspulas of the anteroconid) was found only in one case. Additional morphological elements (anterostylid, mesolophid, mesoconid, lingual anterolophulid) are completely missing. It has two roots.

$\boldsymbol{M}_{2}$ : It has rectangular outline. Lingual anterocingulum is missing: $10 / 30$, short: $10 / 30$, middle developed: $8 / 30$, or long: $2 / 30$. Short mesolophid is rare $(2 / 30)$, which reaches the posterior basis of the metaconid. There is no mesoconid, but central ring is developed in one case. It has two roots.

$\boldsymbol{M}_{3}$ : It shows subtriangular outline, the entoconid is reduced. Lingual antrocingulum is missing: $7 / 31$, short: $7 / 31$, middle developed: $13 / 31$, or long:

Table 7. Dimensions of Cricetus nanus molars (Beremend 14)

\begin{tabular}{lcccccc}
\hline & & $\mathrm{n}$ & min. & mean & max. & sd. \\
\hline $\mathrm{M}^{1}$ & $\mathrm{~L}$ & 45 & 2.33 & 2.50 & 2.75 & 0.09 \\
& $\mathrm{~W}$ & 45 & 1.48 & 1.63 & 1.75 & 0.08 \\
$\mathrm{M}^{2}$ & $\mathrm{~L}$ & 44 & 1.85 & 1.98 & 2.15 & 0.08 \\
& $\mathrm{~W}$ & 44 & 1.58 & 1.68 & 1.78 & 0.06 \\
$\mathrm{M}^{3}$ & $\mathrm{~L}$ & 37 & 1.33 & 1.60 & 1.75 & 0.13 \\
& $\mathrm{~W}$ & 37 & 1.20 & 1.43 & 1.70 & 0.11 \\
\hline $\mathrm{M}_{1}$ & $\mathrm{~L}$ & 41 & 2.23 & 2.32 & 2.53 & 0.06 \\
& $\mathrm{~W}$ & 41 & 1.28 & 1.39 & 1.53 & 0.06 \\
$\mathrm{M}_{2}$ & $\mathrm{~L}$ & 30 & 1.80 & 1.90 & 2.05 & 0.07 \\
& $\mathrm{~W}$ & 30 & 1.38 & 1.55 & 1.65 & 0.06 \\
$\mathrm{M}_{3}$ & $\mathrm{~L}$ & 31 & 1.68 & 1.92 & 2.18 & 0.12 \\
& $\mathrm{~W}$ & 30 & 1.35 & 1.47 & 1.65 & 0.08 \\
\hline
\end{tabular}


4/31. Mesolophid is missing: $8 / 31$, it is short, does not reach the posterior basis of the metaconid: $2 / 31$. It reaches the posterior basis of the metaconid:21/31. A central ring is missing: $11 / 31$, or developed: $20 / 31$. Two roots.

Remarks - Originally this hamster was described as a subspecies, Cricetus cricetus nanus (Schaub, 1930). But on the basis of the metrical and morphological characters and also their stratigraphical range Hír regarded this taxon as a distinct species: Cricetus nanus (Hír 1994, 1997).

Related to the other $C$. nanus populations studied by Hír (1994) the material of Beremend 14 is special because of the relatively small dimensions and the more frequent mesolophids and central rings in the morphology of $M_{3}$. These characters suggest that the larger hamster from Beremend 14 can be an early representative of $C$. nanus (Figs 31-32).

The flourishing of the species is experienced in the typical Allophaiomys faunas without progressive Microtus and Pitymys species (Poland: Zabia; Bohemia: Chlum 6; Slovakia: Kolinany 3, Vcelare 3b/1, Vcelare 4a/5, Vcelare 4a/7, Vcelare 4e, Vcelare 5, Vcelare 6; Hungary: Osztramos 2, Osztamos 8, Osztramos 14; Romania: Betfia 2, Betfia 10; Russia: Akkulaevo 2, Akkulaevo 3) (Hír 1994). Later the presence of $C$. nanus with reduced abundance was verified in the fauna of the Somssich Hill 2 (Hír 1998). The last occurrence of C. nanus was found in the 12th level of the Tarkö Rock-shelter (Hír 1994).

Up to the present we had no data on the ancestors and the origin of this hamster.

\section{Subfamily Arvicolinae Gray, 1821}

Abbreviations used in the voles $\mathrm{M}_{1}$ descriptions: $\mathrm{L}=$ length of occlusal surface, $\mathrm{A}=$ anteroconid length, $\mathrm{W}=$ width of occlusal surface, $\mathrm{B}=$ the shortest distance between BRA3 and LRA4, C = the shortest distance between BRA3 and LRA3, Asd = anterosinuid height, Hsd = hyposinuid height, Hsld = hyposinulid height, $\mathrm{A} / \mathrm{L}=\mathrm{A} \times 100 / \mathrm{L}, \mathrm{B} / \mathrm{W}=\mathrm{B} \times 100 / \mathrm{W}, \mathrm{C} / \mathrm{W}=\mathrm{C} \times 100 / \mathrm{W}$ (Fig. 33). Morphological terms are used after Rekovets \& NADACHOwsKi (1995) and TesAkov (2004). Measurements are given in $\mathrm{mm}$.

Genus Dolomys Nehring, 1898

Dolomys milleri Nehring, 1898

(Fig. 34)

Material -1 right $\mathrm{M}_{1}(\mathrm{~L}=3.72, \mathrm{~A}=1.80, \mathrm{~W}=1.44, \mathrm{Hsd}=0.68, \mathrm{Hsld}=0.40$, $\mathrm{A} / \mathrm{L}=48.38)$. 
a

\section{$\mathbf{M}_{1}$}
C. nanus, Somssich-hegy 2
C. nanus, Betfia 2
C. nanus, Osztramos 14
C. nanus, Osztramos 8
C. nanus, Beremend 14
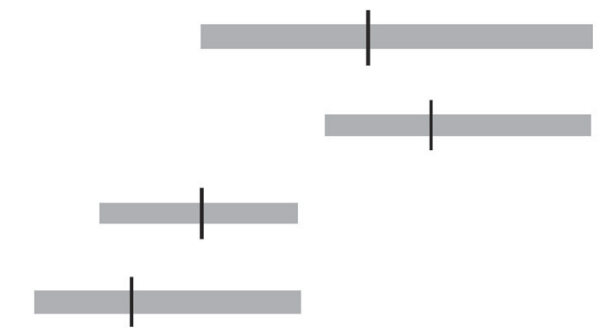

A. ehiki, Beremend 14

A. chiki, Villány 3

A. ehiki, Osztramos 3

\begin{tabular}{|c|c|c|c|c|c|c|c|c|c|c|c|c|c|}
\hline 1 & $T$ & $T$ & $T$ & $T$ & $T$ & $T$ & $T$ & T & $T$ & $T$ & T & T & \\
\hline 1.6 & 1.7 & 1.8 & 1.9 & 2.0 & 2.1 & 2.2 & 2.3 & 2.4 & 2.5 & 2.6 & 2.7 & 2.8 & 2.9 \\
\hline
\end{tabular}

b

C. nanus, Somssich-hegy 2

$\mathbf{M}^{1}$

C. nanus, Betfia 2

C. nanus, Osztramos 14

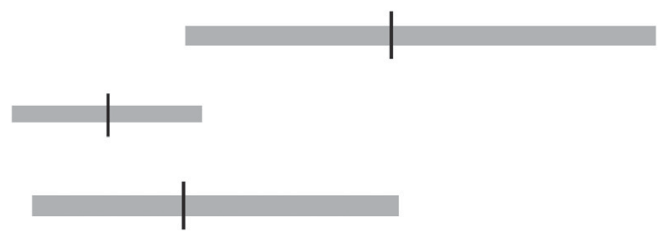

C. nanus, Beremend 14

A. ehiki, Beremend 14

A.ehiki, Villány 3

A. ehiki, Osztramos 3

\begin{tabular}{|c|c|c|c|c|c|c|c|c|c|c|c|c|c|}
\hline 1 & 1 & 1 & $T$ & $T$ & $T$ & $T$ & $T$ & 1 & $T$ & 1 & $T$ & $\top$ & $T$ \\
\hline 1.8 & 1.9 & 2.0 & 2.1 & 2.2 & 2.3 & 2.4 & 2.5 & 2.6 & 2.7 & 2.8 & 2.9 & 3.0 & 3.1 \\
\hline
\end{tabular}

Fig. 31. A comparison of the min.-mean-max. ranges of $M_{1}$ length (a) and $M^{1}$ length (b) of some Allocricetus ehiki and Cricetus nanus populations 


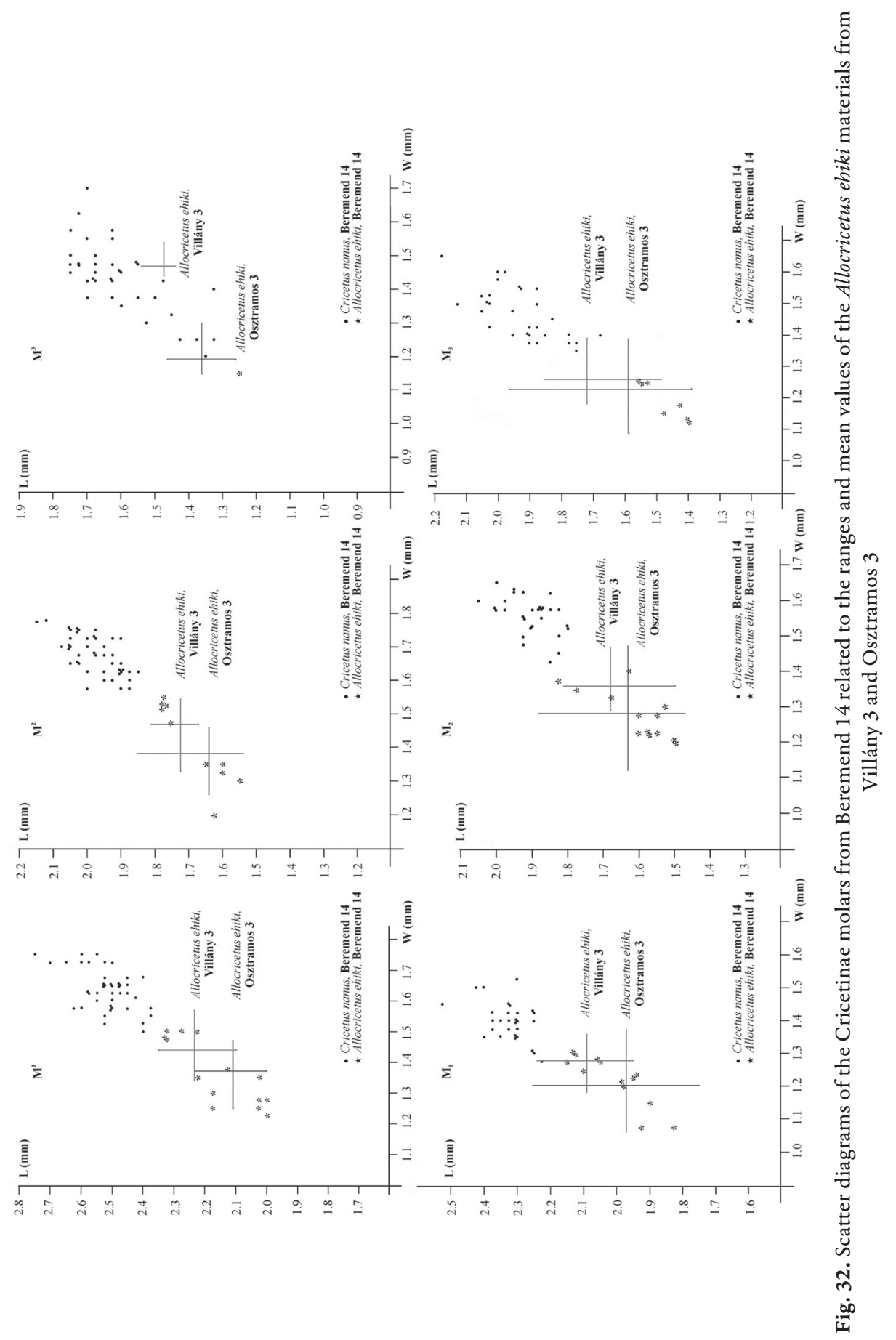




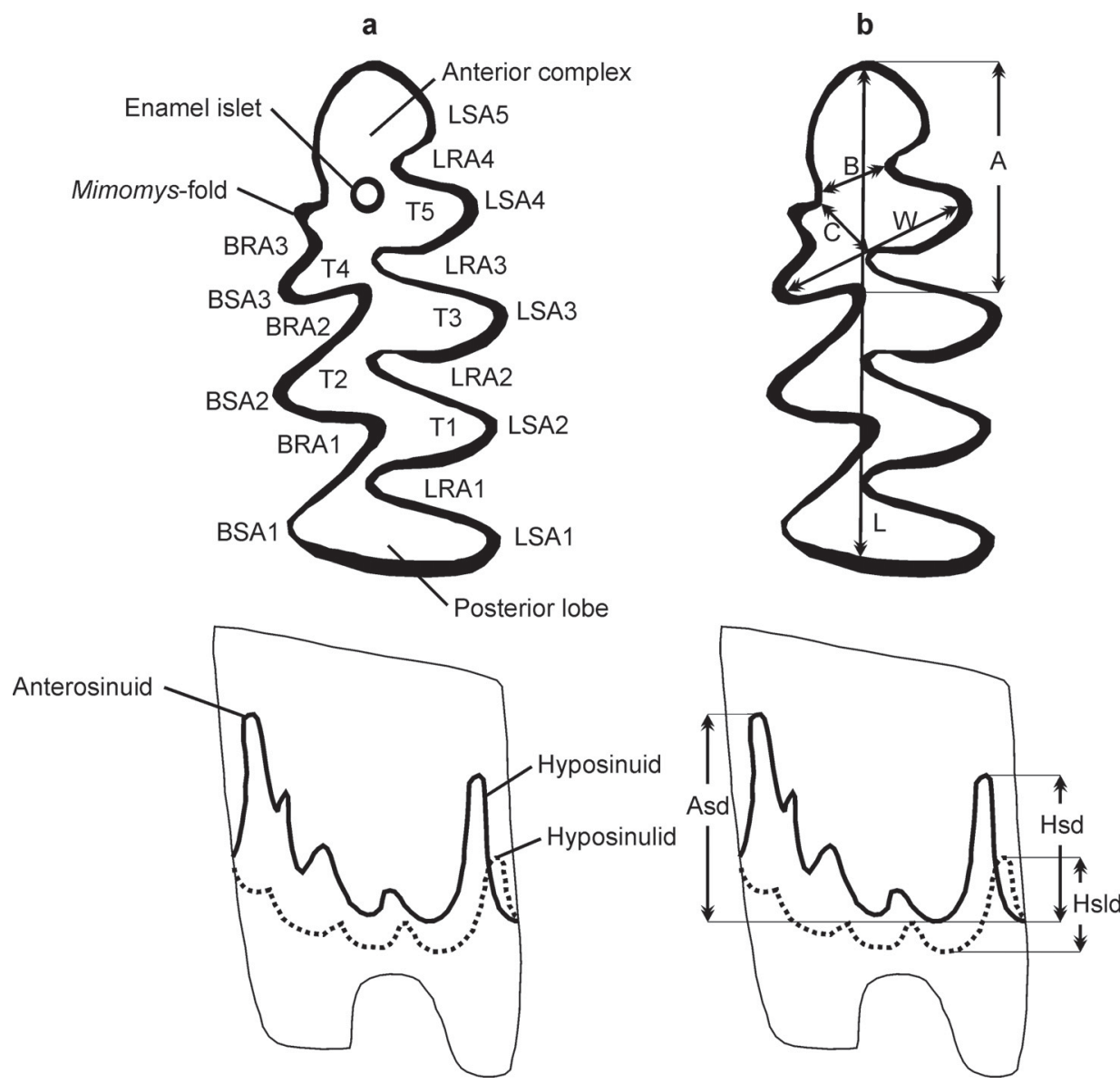

Fig. 33. a. Terminology used in the description of vole $M_{1}$. $B R A=$ buccal re-entrant angle, $B S A=$ buccal salient angle, $\mathrm{LRA}=$ lingual re-entrant angle, $\mathrm{LSA}=$ lingual salient angle, $\mathrm{T}=$ triangle. $\mathbf{b}$. Measuring methods for vole $M_{1}$. For explanation see text

Description - Large, rooted tooth with pointed triangles. Cementum is missing. Its enamel shows Mimomys-like or negative enamel differentiation (thicker trailing enamel edges than their complementary leading edges).

Genus Villanyia Kretzoi, 1956

Villanyia exilis Kretzoi, 1956

(Fig. 35)

Material - 1 left $\mathrm{M}_{1}(\mathrm{~L}=2.30, \mathrm{~A}=0.93, \mathrm{~W}=0.96, \mathrm{Asd}=1.50, \mathrm{Hsd}=1.07$, Hsld $=0.43, \mathrm{~A} / \mathrm{L}=40.43$ ). 
Description - Small tooth without cementum, Mimomys-fold or enamel islet. Its enamel shows Microtus-like or positive enamel differentiation (thicker leading enamel edges than their complementary trailing edges).

Genus Mimomys F. Mayor, 1902

Mimomys reidi Hinton, 1910

(Fig. 36)

Material - Isolated teeth: 65 right $\mathrm{M}_{1} ; 65$ left $\mathrm{M}_{1}$.

Measurements - Table 8.

Description - In most cases, teeth have cementum, Mimomys-fold and enamel islet. Their enamel shows Mimomys-like or negative enamel differentiation.

Table 8. Measurements of Mimomys reidi $\mathrm{M}_{1}$ (Beremend 14)

\begin{tabular}{lccccc}
\hline & $\mathrm{n}$ & min. & mean & max. & sd. \\
\hline $\mathrm{L}$ & 125 & 2.27 & 2.87 & 3.33 & 0.16 \\
$\mathrm{~A}$ & 57 & 0.90 & 1.07 & 1.37 & 0.11 \\
$\mathrm{~W}$ & 109 & 0.63 & 1.19 & 1.40 & 0.11 \\
Asd & 6 & 2.73 & 2.92 & 3.33 & 0.21 \\
Hsd & 6 & 2.00 & 2.44 & 2.67 & 0.28 \\
Hsld & 57 & 1.33 & 1.71 & 2.10 & 0.19 \\
A/L & 57 & 31.76 & 38.13 & 48.72 & 3.89 \\
\hline
\end{tabular}

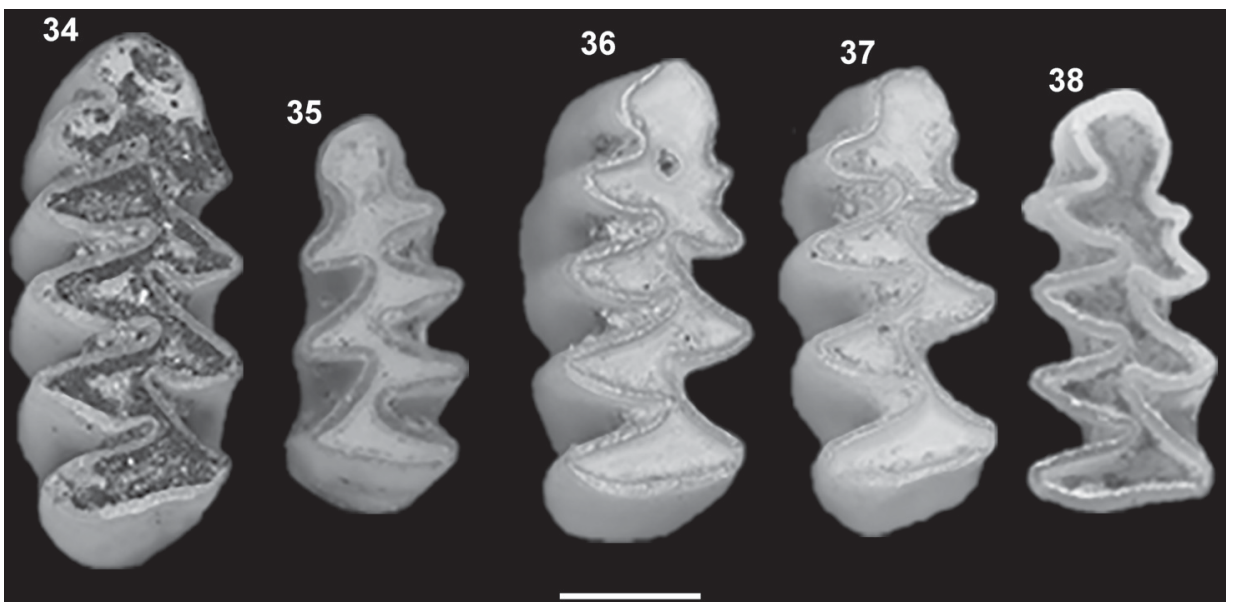

Fig. 34. Dolomys milleri Nehring, 1898; right $\mathrm{M}_{1}$ (VER 2016.3573.9.). - Fig. 35. Villanyia exilis Kretzoi, 1956; left $M_{1}$ (VER 2016.3573.10.). - Fig. 36. Mimomys reidi Hinton, 1910; right $\mathrm{M}_{1}$ (VER 2016.3573.11.). - Fig. 37. Mimomys pusillus (Méhely, 1914); right $M_{1}$ (VER 2016.3573.12.). - Fig. 38. Pitymimomys pitymyoides (Jánossy et van der Meulen, 1975); right $M_{1}$ (VER 2016.3573.13.). All occlusal views, scale bar $=1 \mathrm{~mm}$ 
Mimomys pusillus (Méhely, 1914)

(Fig. 37)

Material - Isolated teeth: 46 right $\mathrm{M}_{1} ; 30$ left $\mathrm{M}_{1}$.

Measurements - Table 9.

Description - In most cases, teeth have cementum and Mimomys-fold. Their enamel shows Mimomys-like or negative enamel differentiation.

Table 9. Measurements of Mimomys pusillus $\mathrm{M}_{1}$ (Beremend 14)

\begin{tabular}{lccccc}
\hline & $\mathrm{n}$ & min. & mean & $\max$. & $\mathrm{sd}$. \\
\hline $\mathrm{L}$ & 41 & 2.40 & 2.63 & 2.77 & 0.08 \\
$\mathrm{~A}$ & 41 & 0.87 & 0.99 & 1.27 & 0.07 \\
$\mathrm{~W}$ & 40 & 0.97 & 1.07 & 1.17 & 0.06 \\
Asd & 2 & 2.63 & 2.90 & 3.17 & 0.38 \\
Hsd & 2 & 2.23 & 2.28 & 2.33 & 0.07 \\
Hsld & 21 & 1.17 & 1.83 & 2.13 & 0.23 \\
A/L & 41 & 33.33 & 37.64 & 45.78 & 2.28 \\
\hline
\end{tabular}

Genus Pitymimomys Tesakov, 1998

Pitymimomys pitymyoides (Jánossy et van der Meulen, 1975)

(Fig. 38)

Material - Isolated teeth: 11 right $\mathrm{M}_{1} ; 17$ left $\mathrm{M}_{1}$.

Measurements - Table 10.

Description - Middle-sized teeth with Mimomys-fold. Broad communications are present between triangles at the occlusal surface. The enamel thickness is nearly always uniform.

Table 10. Measurements of Pitymimomys pitymyoides $\mathrm{M}_{1}$ (Beremend 14)

\begin{tabular}{lccccc}
\hline & $\mathrm{n}$ & min. & mean & max. & sd. \\
\hline $\mathrm{L}$ & 19 & 2.33 & 2.53 & 2.73 & 0.12 \\
$\mathrm{~A}$ & 19 & 0.83 & 1.02 & 1.20 & 0.08 \\
$\mathrm{~W}$ & 19 & 0.97 & 1.05 & 1.20 & 0.06 \\
Asd & 2 & 3.00 & 3.17 & 3.33 & 0.24 \\
Hsd & 3 & 2.60 & 2.72 & 2.83 & 0.12 \\
Hsld & 4 & 2.07 & 2.48 & 2.90 & 0.38 \\
A/L & 19 & 35.71 & 40.36 & 45.00 & 2.62 \\
\hline
\end{tabular}


Genus Borsodia Jánossy et van der Meulen, 1975

Borsodia newtoni (F. Major, 1902)

(Fig. 39)

Material - 1 right mandible with $\mathrm{M}_{1-3} ; 2$ right mandible fragments with $\mathrm{M}_{1}$; 1 left mandible fragment with $M_{1} ; 2$ left mandible fragments with $M_{1-2}$; Isolated teeth: 60 right $M_{1} ; 60$ left $M_{1}$.

Measurements - Table 11.

Description - Middle-sized, rooted teeth without cementum. Their enamel shows Microtus-like or positive enamel differentiation.

Table 11. Measurements of Borsodia newtoni $\mathrm{M}_{1}$ (Beremend 14)

\begin{tabular}{lccccc}
\hline & $\mathrm{n}$ & min. & mean & $\max$. & sd. \\
\hline $\mathrm{L}$ & 33 & 2.23 & 2.50 & 2.77 & 0.13 \\
$\mathrm{~A}$ & 33 & 0.83 & 1.04 & 1.23 & 0.09 \\
$\mathrm{~W}$ & 33 & 0.90 & 1.05 & 1.20 & 0.07 \\
Asd & 6 & 1.83 & 2.29 & 2.80 & 0.35 \\
Hsd & 5 & 1.97 & 2.10 & 2.23 & 0.11 \\
Hsld & 26 & 1.13 & 1.53 & 2.00 & 0.25 \\
A/L & 33 & 36.36 & 41.54 & 46.84 & 2.84 \\
\hline
\end{tabular}

Genus Allophaiomys Kormos, 1932

Allophaiomys deucalion Kretzoi, 1969

(Fig. 40)

Material - 1 left mandible fragment with $M_{1}$; Isolated teeth: 2 right $M_{1} ; 1$ left $\mathrm{M}_{1}$.

Measurements - Table 12.

Table 12. Measurements of Allophaiomys deucalion $\mathrm{M}_{1}$ (Beremend 14)

\begin{tabular}{lccccc}
\hline & $\mathrm{n}$ & min. & mean & $\max$. & sd. \\
\hline $\mathrm{L}$ & 4 & 2.27 & 2.48 & 2.70 & 0.19 \\
$\mathrm{~A}$ & 4 & 1.03 & 1.08 & 1.20 & 0.08 \\
$\mathrm{~W}$ & 4 & 0.93 & 0.98 & 1.03 & 0.05 \\
$\mathrm{~B}$ & 4 & 0.23 & 0.33 & 0.40 & 0.07 \\
$\mathrm{C}$ & 4 & 0.27 & 0.28 & 0.30 & 0.02 \\
$\mathrm{~A} / \mathrm{L}$ & 4 & 41.56 & 43.66 & 45.59 & 1.74 \\
$\mathrm{~B} / \mathrm{W}$ & 4 & 25.00 & 33.24 & 40.00 & 6.34 \\
$\mathrm{C} / \mathrm{W}$ & 4 & 26.67 & 28.21 & 29.03 & 1.05 \\
\hline
\end{tabular}




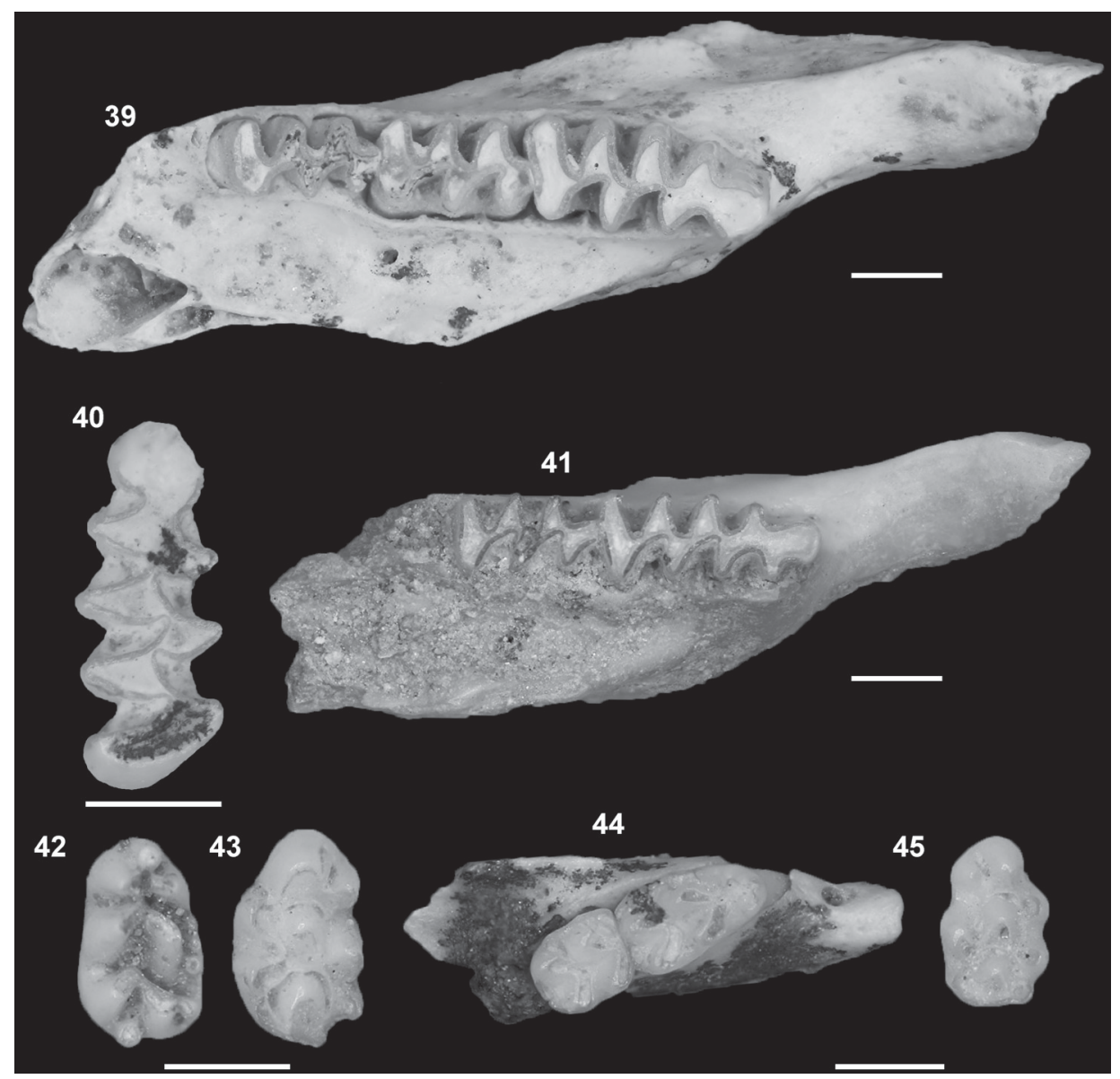

Fig. 39. Borsodia newtoni (F. Major, 1902); right mandible with $\mathrm{M}_{1-3}$ (VER 2016.3573.14.). - Fig. 40. Allophaiomys deucalion Kretzoi, 1969; right $\mathrm{M}_{1}$ (VER 2016.3573.15.). - Fig. 41. Lagurodon arankae (Kretzoi, 1954); right mandible fragment with $\mathrm{M}_{1-2}$ (VER 2016.3573.16.). - Figs 42-43. Apodemus dominans Kretzoi, 1959. - 42. Right $\mathrm{M}_{1}$ (VER 2016.3573.17.). - 43. Left $\mathrm{M}^{1}$ (VER 2016.3573.18.). - Figs 44-45. Micromys praeminutus Kretzoi, 1959. - 44. Left mandible fragment with $M_{1-2}$ (VER 2016.3573.19.). - 45. Right $\mathrm{M}^{1}$ (VER 2016.3573.20.). All occlusal views, scale bars $=1 \mathrm{~mm}$

Description - Middle-sized, rootless teeth with cementum. Their enamel shows Microtus-like or positive enamel differentiation.

Genus Lagurodon Kretzoi, 1956

Lagurodon arankae (Kretzoi, 1954)

(Fig. 41) 
Material - 1 right mandible fragment with $\mathrm{M}_{1-2} ; 1$ right mandible fragment with $\mathrm{M}_{1}$; 6 left mandible fragments with $\mathrm{M}_{1-2}$; Isolated teeth: 61 right $\mathrm{M}_{1} ; 65$ left $\mathrm{M}_{1}$.

Measurements - Table 13.

Description - Small-sized, hypsodont, rootless teeth without cementum. The enamel thickness is nearly always uniform.

Table 13. Measurements of Lagurodon arankae $\mathrm{M}_{1}$ (Beremend 14)

\begin{tabular}{lccccc}
\hline & $\mathrm{n}$ & min. & mean & max. & sd. \\
\hline $\mathrm{L}$ & 4 & 2.27 & 2.48 & 2.70 & 0.19 \\
$\mathrm{~A}$ & 4 & 1.03 & 1.08 & 1.20 & 0.08 \\
$\mathrm{~W}$ & 4 & 0.93 & 0.98 & 1.03 & 0.05 \\
$\mathrm{~B}$ & 4 & 0.23 & 0.33 & 0.40 & 0.07 \\
$\mathrm{C}$ & 4 & 0.27 & 0.28 & 0.30 & 0.02 \\
$\mathrm{~A} / \mathrm{L}$ & 4 & 41.56 & 43.66 & 45.59 & 1.74 \\
$\mathrm{~B} / \mathrm{W}$ & 4 & 25.00 & 33.24 & 40.00 & 6.34 \\
$\mathrm{C} / \mathrm{W}$ & 4 & 26.67 & 28.21 & 29.03 & 1.05 \\
\hline
\end{tabular}

Family Muridae Illiger, 1811

Genus Apodemus Kaup, 1829

Apodemus dominans Kretzoi, 1959

(Figs 42-43)

Material - Isolated teeth: 4 right $M_{1} ; 2$ left $M_{1} ; 1$ right $M_{2} ; 1$ right $M_{3} ; 1$ right $\mathrm{M}^{1} ; 2$ left $\mathrm{M}^{1} ; 1$ right $\mathrm{M}^{2} ; 1$ left $\mathrm{M}^{2}$.

Measurements - Table 14.

Description - Late Pliocene mouse, which belongs to the Apodemus sylvaticus group.

Table 14. Measurements of Muridae material (Beremend 14)

\begin{tabular}{lcccccc}
\hline Apodemus dominans & & $\mathrm{n}$ & min. & mean & max. & sd. \\
\hline $\mathrm{M}_{1}$ & $\mathrm{~L}$ & 4 & 1.64 & 1.73 & 1.88 & 0.11 \\
& $\mathrm{~W}$ & 4 & 1.00 & 1.04 & 1.12 & 0.06 \\
$\mathrm{M}^{1}$ & $\mathrm{~L}$ & 3 & 1.88 & 1.96 & 2.00 & 0.07 \\
& $\mathrm{~W}$ & 3 & 1.16 & 1.21 & 1.24 & 0.05 \\
\hline Micromys praeminutus & & $\mathrm{n}$ & min. & mean & max. & $\mathrm{sd}$. \\
\hline $\mathrm{M}_{1}$ & $\mathrm{~L}$ & 9 & 1.32 & 1.43 & 1.48 & 0.06 \\
& $\mathrm{~W}$ & 9 & 0.72 & 0.80 & 0.88 & 0.05 \\
$\mathrm{M}^{1}$ & $\mathrm{~L}$ & 6 & 1.44 & 1.49 & 1.52 & 0.03 \\
& $\mathrm{~W}$ & 6 & 0.92 & 0.97 & 1.04 & 0.04 \\
\hline
\end{tabular}


Genus Micromys Dehne, 1841

Micromys praeminutus Kretzoi, 1959

(Figs 44-45)

Material - 1 left mandible fragment with $\mathrm{M}_{1} ; 1$ left mandible fragment with $M_{1-2}$; Isolated teeth: 4 right $M_{1} ; 4$ left $M_{1} ; 1$ right $M_{2} ; 1$ left $M_{2} ; 3$ right $M^{1} ; 3$ left $\mathrm{M}^{1}$; 1 right $\mathrm{M}^{2}$.

Measurements - Table 14.

Description - Very small-sized mouse. The additional cusps are missing in its molars, although an enamel rib replacing them, which is similar to Apodemus.

\section{BIOSTRATIGRAPHY}

The previous studies, mainly related to the Late Pliocene Beremend 26 site, found that the filling up of karstic cavities was episodic, it linked sheet washes. As a result, infillings represent a longer interval, at least $200 \mathrm{kyr}$ (MARSI \& Koloszár 2004).

Many long-lived species are present in the Beremend 14 shrews. Sorex runtonensis is one of the most abundant representatives of its genus in the European Pleistocene. Its oldest record dates from the MN 17 zone, the youngest ones are known from several Late Pleistocene localities (Osipova et al. 2006). Sorex minutus appears in the Early Pliocene MN 14 Zone (RZEBIK-KowalsKa 1991), it is present in the Hungarian fossil fauna to the uppermost Pleistocene (MÉszáros 1999 ) and is still living. Beremendia fissidens is also reported from the MN 14 Zone to the Tarkőian Phase of the Middle Pleistocene in Europe (ВоткA \& MÉszÁros 2014).

Contrarily, some of the shrews are used to determine the age of the locality. Petenyia hungarica shows a long stratigraphic range from the Miocene/Pliocene boundary (MN 13/14 Zone) to the end of the Early Pleistocene (RzEBIKKowALSKa 2000). The first occurrence of Asoriculus gibberodon in Hungary is reported by MÉszÁros (1998) from the Late Miocene MN 12 Zone and it occurs to the end of the Early Pleistocene (RzEBIK-Kowals Ka 2000). The first report on Crocidura kornfeldi in the European mainland is from the boundary of the MN 16 and MN 17 Zone from Greece. It disappeared from the continent in the Middle Pleistocene (Bot KA \& MÉszÁros 2015). Sorex (Drepanosorex) savini is reported from the Early Pleistocene MN 17 Zone until the Late Biharian Stage of the Middle Pleistocene (BоткA \& MÉszÁros 2016). The simultaneous occurrence of these four species determines the age of Beremend 14 locality to be neither older nor younger than the Early Pleistocene. 
Some modifications can be made within this period by the significant attendance of Asoriculus in the fauna. Despite of its sporadic occurrence to the end of the Early Pleistocene (JÁnossy 1986), the sure presence of Asoriculus gibberodon in Hungary is reported only to the end of the MN 17 Zone (REUMER 1984).

On the basis of simultaneous occurrences of rodents, mainly the shortranged voles, the age of Beremend 14 site was further refined. Naturally, there are many long-lived rodent species also present in the fauna. Spermophilus primigenius was a frequent species from the MN 17 Zone to Middle Pleistocene mainly in Central Europe (Jánossy 1986; Reumer \& Hoek Ostende 2003). Glis minor appears in the Early Pliocene MN 14 Zone (LINDSAY et al. 2013), but is also present in the late Early Pleistocene (STRICZKY \& PAZONY 2014). Apodemus dominans is also a long-lived species, it appeared in the latest Turolian MN 13 Zone and disappeared at the end of the Pliocene (WANG \& FLYNN 2013). The other mouse species, Micromys praeminutus, is reported from the Early Pliocene MN 15 Zone to the Middle Pleistocene MQ2 Zone (JÁnOssY 1986; HorÁČEK et al. 2013). Sicista praeloriger appears in the Late Pliocene MN 16 Zone (Beremend 15; JÁNOSSY 1987), and survives until the end of the MQ 1 Zone (Lindsay et al. 2013). Prospalax priscus as well appears in the MN 16A Zone and disappears in the MQ 1 Zone, at the end of the Mimomys savini/Mimomys pusillus Biozone (Jánossy 1986; Lindsay et al. 2013). Allocricetus cf. ehiki appeared in the Late Miocene (MN 10-11) in the Eastern Mediterranean, but in Central Europe it is known only from the Late Pliocene up to the Middle Pleistocene.

Ranges of other rodents are much shorter. Some rodents are typical Late Pliocene species: Dolomys milleri (MN 15B-MN 17) (LINDSAY et al. 2013) and Estramomys simplex (MN 16A - end of MN 17) (FEJFAR \& HoRÁČEK 1983; JÁNOSSY 1986; LiNDSAY et al. 2013), other ones appear at the end of the MN 17 Zone: Villanyia exilis (JÁnossy 1986), Allophaiomys deucalion, Lagurodon arankae (Tesa Kov 2004), Cricetus nanus. However, some of the voles (Borsodia newtoni, Mimomys reidi, Pitymimomys pitymyoides) lived solely in the MN 17 Zone (JÁnOSSY 1986; TESAKOV 2004). Thus we suppose that the stratigraphic position of the site is the MN 17 Zone (Fig. 46).

\section{PALAEOECOLOGY}

Based on the previous clay mineral studies, filling up of the Beremend 26 site occurred in humid, warm Mediterranean or subtropical climate (MARSI \& Koloszár 2004). However, some younger, Early Pleistocene, red clay infillings were also found in the Beremend quarry, which are composed of clay minerals suggesting semiarid climate (DEzső et al. 2007). 


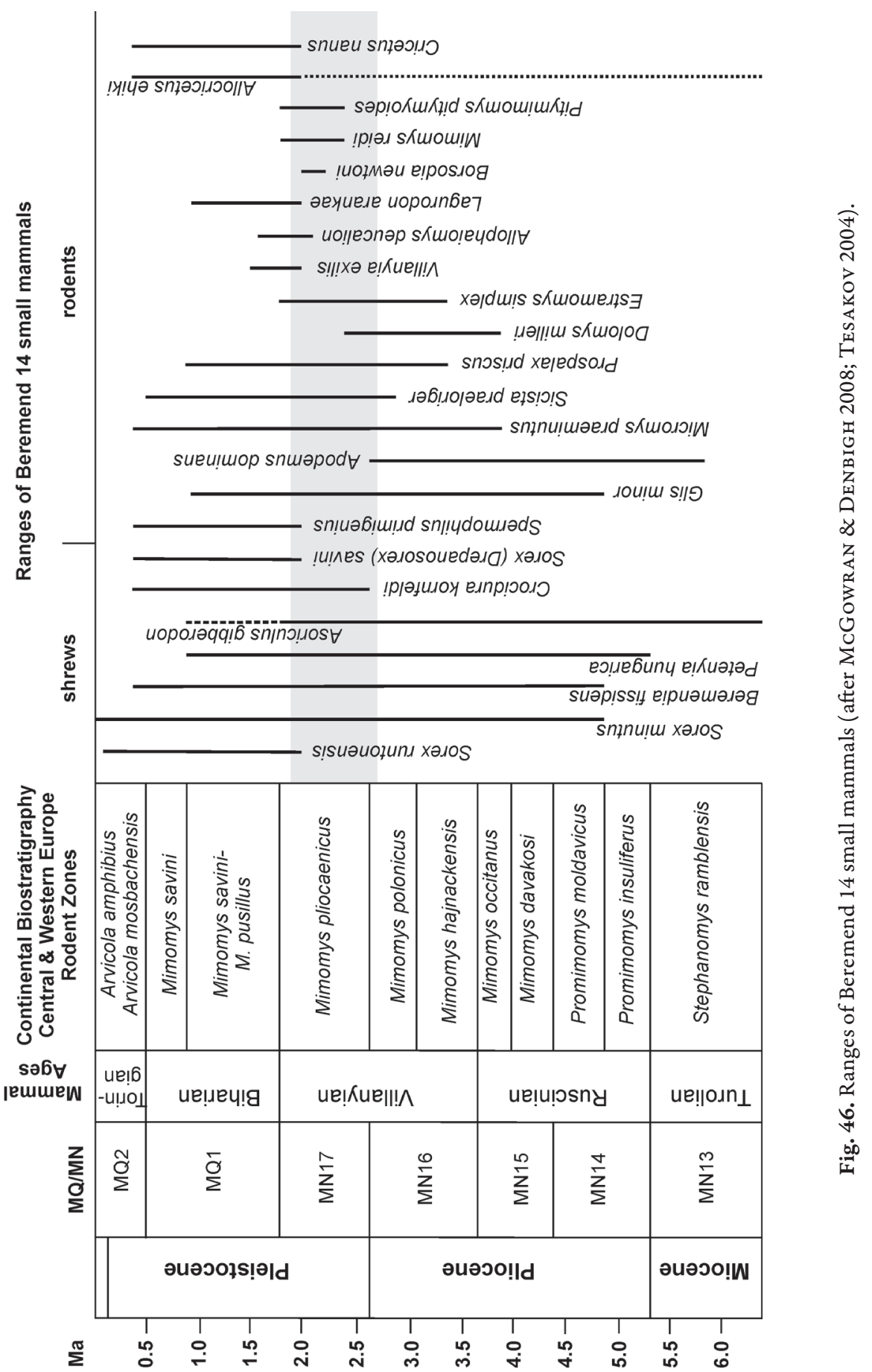


The ecological compound of the Soricidae fauna is varied. Crocidura prefers warm climate and dry terrains, with more or less open grasslands. Sorex runtonensis is also an indicator of arid and relatively open environments (OsIPova et al. 2006). Sorex minutus and Asoriculus gibberodon indicate a humid environment with a good covering of vegetation (REUMER 1984; RZEBIK-KOWALSKA 1995). The presence of open water is marked by Sorex (Drepanosorex) savini (REUMER 1984; Maul \& PARfitt 2010). Beremendia and Petenyia are typified by ReUmer (1984) as opportunist and ubiquitous genera. Conversely, Bot KA \& MÉszÁros (2014) raised that the occurrence of Beremendia is connected with open water in most of the paleobiotopes. Since it is unproved Beremendia is ranged to the "water-indicator or opportunist" group in our ecotype reconstruction (Fig. 47).

The ecological composition of the shrew fauna shows a significant rate of water-preferring (and "possibly riparian") forms, which indicates an open water surface, perhaps with a good vegetation cover. It is supported by the presence of some forest shrews, too. At the same time we suppose the dominance of open grassland ecotypes in the wider surroundings because of the great number of the steppe indicators (Sorex runtonensis and Crocidura kornfeldi).
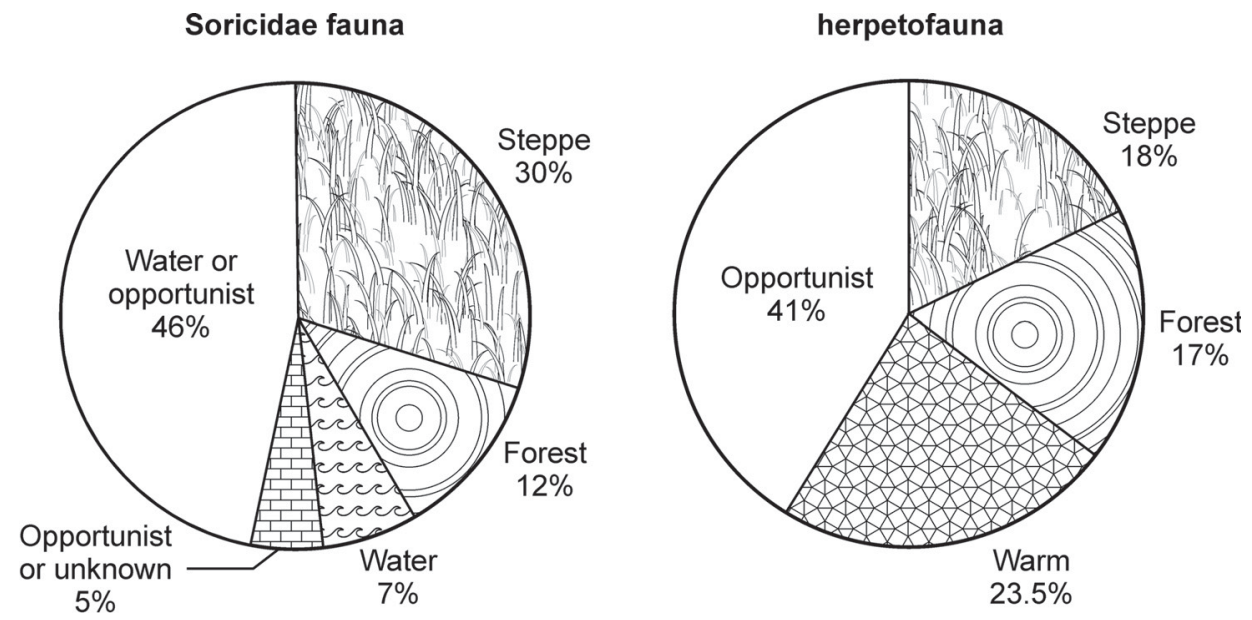

Fig. 47. Ecological composition of the Soricidae and the herpetofauna (\% of MNI). Shrews steppe forms: Crocidura kornfeldi and Sorex runtonensis; forest species: Sorex minutus and Asoriculus gibberodon; open water indicator: Sorex (Drepanosorex) savini; opportunist or unknown: Petenyia hungarica and Soricidae gen. et sp. indet.; water indicator or opportunist: Beremendia fissidens. Herpetofauna - steppe forms: Pelobates fuscus, Bufo bufo, B. viridis, Bufo sp.; forest species: Hyla arborea, Anguidae indet., Coronella austriaca, Zamenis longissimus; warm indicator species: Coluber viridiflavus, C. gemonensis, Elaphe quatuorlineata, Telescopus fallax; opportunist: Bombina variegata, Rana temporaria, Rana sp., Natrix natrix, N. tessalata, Natrix sp. 
Hamsters and some voles (Mimomys reidi, Borsodia newtoni, Lagurodon arankae) are dominant among rodents. Unfortunately, ecological needs of these extinct voles are unknown, but the dominance of hamsters suggests open habitat, probably grassland. This conclusion is also justified by the insignificant dormice and mice material.

The herpetofauna and its ecological composition show a similar picture as shrews. The ratio of the water indicator species (Triturus cristatus, Lissotriton vulgaris) is negligible, however, opportunistic forms show high ratio (41\%). Proportion of the forms preferring open habitat and forest species is equal (17$18 \%$ ), but the warm indicator species (Coluber viridiflavus, C. gemonensis, Elaphe quatuorlineata, Telescopus fallax) appear in significant amounts (23.5\%) in the herpetofauna (Fig. 47).

The palaeoecological analysis suggests warm, dry climate and open, probably wooded grassland vegetation in the surroundings of the site with smaller open water surface. Our results confirm the previous concepts (DEzsö et al. 2007; PAzONYi 2006, 2011) about the Early Pleistocene climate and vegetation in the region.

Acknowledgements - We would like to render thanks to Mihály Gasparik (Department of Palaeontology and Geology, Hungarian Natural History Museum, Budapest) for the material studied here and to Márton Szabó for his kind help in the preparation of the plates. The study was supported by the Hungarian Scientific Research Fund (OTKA K 115472). This is MTA-MTM Paleo contribution No. 233.

\section{REFERENCES}

Botka D. \& MÉszÁros L. 2014: Beremendia (Mammalia, Soricidae) remains from the late Early Pleistocene Somssich Hill 2 locality (Southern Hungary) and their taxonomic, biostratigraphical, palaeoecological and palaeobiogeographical relations. - Fragmenta Palaeontologica Hungarica 31: 83-115. http://dx.doi.org/10.17111/FragmPalHung.2014.31.83

Bot KA D. \& MÉSZÁros L. 2015: Crocidura (Mammalia, Soricidae) remains from the late Early Pleistocene Somssich Hill 2 locality (Villány Hills, Southern Hungary). - Fragmenta Palaeontologica Hungarica 32: 67-98. http://dx.doi.org/10.17111/FragmPalHung.2015.32.67

Bot KA D. \& MÉszÁros L. 2016: Sorex (Mammalia, Soricidae) remains from the late Early Pleistocene Somssich Hill 2 locality (Villány Hills, Southern Hungary). - Fragmenta Palaeontologica Hungarica 33: 135-154. http://dx.doi.org/10.17111/FragmPalHung.2016.33.135

CsászáR G. \& Kordos L. 2004: Beremend, kőfejtő. [Beremend, quarry] - Program, elöadáskivonatok, kirándulásvezetö, 7. Magyar Öslénytani Vándorgyülés, Beremend 2004. május 6-8, pp. 51-57.

Cuenca-Bescos G. 2003: Análisis filogenético de Allocricetus del Pleistoceno (Cricetidae, Rodentia, Mammalia). - Coloquios de Paleontologia Vol. Ext. 1: 95-113. 
DaAms R. \& Freudenthal M. 1988: Cricetidae (Rodentia) from the type-Aragonian; the genus Megacricetodon. - Scripta Geologica Special Issue 1: 39-132.

DAXNER-Höck G. 1995: Some Glirids and Cricetids from Maramena and other late Miocene localities in Northern Greece. - In: Schmidt-Kittrer N. (ed.): The Vertebrate Locality Maramena (Macedonia, Greece) at the Turolian/Ruscinian Boundary (Neogene) - Münchner Geowissenschaftliche Abhandlungen A28: 103-120.

Dezsö J., RAUCsı́ B. \& VicziÁN I. 2007: Villányi-hegységi karsztos hasadékkitöltések szemcseösszetételi és ásványtani vizsgálata. [Granulometric and mineralogical analysis of karstic fissure filling sediments in the Villány Mts. (S Hungary).] - Acta GGM Debrecina, Geology, Geomorphology, Physical Geography Series 2: 151-180.

FeJfAR O. \& HorÁČEK I. 1983: Zur Entwicklung der Kleinsäugerfaunen im Villányium und AltBiharium auf dem Gebiet der CSSR. - Schriftenreihe für Geologische Wissenschaften 19(20): 111-207.

Hinton M. A. C. 1911: I. The British Fossil Shrews. - Geological Magazine (Decade V) 8(12): 529-539.

HíR J. 1993: Allocricetus éhiki Schaub, 1930 (Rodentia, Mammalia) finds from Villány 3 and Esztramos 3 (Hungary). - Fragmenta Mineralogica et Palaeontologica 16: 61-80.

HíR J. 1994: Cricetus cricetus nanus Schaub, 1930 (Mammalia, Rodentia) finds from the Carpathian Basin. - Annales historico-naturales Musei nationalis hungarici 86: 13-27.

HíR J. 1997: A short scetch of the evolution and stratigraphy of the Plio-Pleistocene cricetids (Rodentia, Mammalia) in Hungary. - Folia Historico-Naturalia Musei Matraensis 22: 43-49.

HíR J. 1998: Cricetids (Rodentia, Mammalia) of the Early Pleistocene vertebrate fauna of Somssichhegy 2 (Southern Hungary, Villány Mountains). - Annales historico-naturales Musei nationalis hungarici 90: $57-89$.

Horáček I., Knitlová M., Wagner J., Kordos L., Nadachowski A. 2013: Late Cenozoic History of the Genus Micromys (Mammalia, Rodentia) in Central Europe. - PLoS ONE 8(5): e62498. http://dx.doi.org/10.1371/journal.pone.0062498

JÁnossy D. 1986: Pleistocene Vertebrate Faunas of Hungary. - Akadémiai Kiadó, Budapest, 208 pp.

JÁnossy D. 1987: Ältestpleistozäne Vertebratenfauna von Beremend 15 (Süd-Ungarn). - Fragmenta Mineralogica et Palaeontologica 13: 89-96.

Kordos L. 1991: Villányi-hegység, Beremend, felső-pliocén ősgerinces lelőhelyek. [Villány Hills, Beremend, Late Pliocene vertebrate localities.] - Magyarország Geológiai Alapszelvényei, Magyar Állami Földtani Intézet, Budapest, pp. 1-6.

Kormos T. 1930: Új adatok a püspökfürdői Somlyóhegy preglaciális faunájához. [New data of the preglacial fauna of Somlyó Hill, Betfia.] - Állattani Közlemények 27: 40-62.

Kretzoi M. 1956: A Villányi hegység alsó-pleisztocén gerinces-faunái. (Die Altpleistozänen Wirbeltierfaunen des Villanyer Gebirges.) - Geologica Hungarica Series Palaeontologica 27: 1-264.

KRETzor M. 1969: A magyarországi quarter és pliocén szárazföldi biosztratigráfiájának vázlata. [Sketch of the Quaternary and Pliocene terrestrial biostratigraphy in Hungary.] - Földrajzi Közlemények 17: 179-204.

KRETzoi M. \& PÉCsI M. 1982: A Pannóniai-medence pliocén és pleisztocén időszakának tagolása. [Division of the Pliocene and Pleistocene in the Pannonian Basin.] - Földrajzi Közlemények 30(4): 300-326.

Krolopp E. 1990: Die Molluskenfaunen der unterpleistozänen Fundstellen Ungarns. - 2uartärpaläontologie 8: 125-130.

Lindsay E. H., FAH Lbusch V. \& MeIN P. 2013: European Neogene Mammal Chronology. - Springer Science \& Business Media, 658 pp. 
MARSi I. \& Koloszár L. 2004: A beremendi Szőlő-hegy pliocén és kvarter képződményei. (Pliocene and Quaternary sediments of the Szőlö Hill in Beremend (SE Transdanubia).) - Földtani Közlöny 134(1): 75-94.

Maul L. C. \& Parfitt S. A. 2010: Micromammals from the 1995 Mammoth Excavation at West Runton, Norfolk, UK: Morphometric data, biostratigraphy and taxonomic reappraisal. Quaternary International 228(1): 91-115. http://dx.doi.org/10.1016/j.quaint.2009.01.005

McGowran B. \& Denbigh K. G. 2008: Biostratigraphy: Microfossils and Geological Time. - Cambridge University Press, $480 \mathrm{pp}$.

Mészáros L. Gy. 1998: Late Miocene Soricidae (Mammalia) fauna from Tardosbánya (Western Hungary). - Hantkeniana 2: 103-125.

MÉszÁros L. Gy. 1999: Uppermost Pleistocene shrews (Mammalia, Soricidae) from Vaskapu Cave, Northern Hungary. - Annales Universitatis Scientiarum Budapestinensis, Sectio Geologica 32: 43-50.

Osipova V. A., Rzebik-Kowalska B. \& Zaitsev M. V. 2006: Intraspecific variability and phylogenetic relationships of the Pleistocene shrew Sorex runtonensis (Soricidae). - Acta Theriologica 51(2): 129-138.

PAzONYi P. 2006: A Kárpát-medence kvarter emlösfauna közösségeinek paleoökológiai és rétegtani vizsgálata. [Palaeoecological and stratigraphical investigations of Quarternary mammalian communities in the Carpathian Basin.] - Unpublished manuscript (PhD Thesis), Magyar Természettudományi Múzeum, Budapest, $115 \mathrm{pp}$.

Pazonyi P. 2011: Palaeoecology of Late Pliocene and Quaternary mammalian communities in the Carpathian Basin. - Acta zoologica cracoviensia 54A(1-2): 1-29. http://dx.doi.org/10.3409/azc.54a_1-2.01-29

Petényi S. J. 1864: Hátrahagyott munkái. [Posthumous works.] - Magyar Tudományos Akadémia, Pest, 130 pp.

Pongrácz L. 1999: A beremendi Szölö-hegy természettudományi kutatásának 150 éve. [Natural sciences research of the Szölö Hill, Beremend during the last 150 years.] - Petényi emlékkönyv, Beremend, 149 pp.

Rekovets L. \& Nadachowski A. 1995: Pleistocene voles (Arvicolidae) of the Ukraine. Paleontologia i Evolucio 28-29: 145-245.

Reumer J. W. F. 1984: Ruscinian and early Pleistocene Soricidae (Insectivora, Mammalia) from Tegelen (The Netherlands) and Hungary. - Scripta Geologica 73: 1-173.

Reumer J. W. F. \& van den Hoek Ostende L. W. 2003: Petauristidae and Sciuridae (Mammalia, Rodentia) from Tegelen, Zuurland, and the Maasvlakte (the Netherlands). - In: REUMER J. W. F. \& Wessels W. (eds): Migration and distribution of Neogene mammals in Eurasia. A volume in honour of Hans De Bruijn. - Deinsea 10: 455-467.

Rummel M. 1998: Die Cricetiden aus dem Mittel- und Obermiozän der Türkei. - Dokumenta Naturae 13: 1-276.

Rzebik-Kowalska B. 1991: Pliocene and Pleistocene Insectivora (Mammalia) of Poland. VIII. Soricidae: Sorex Linnaeus, 1758, Neomys Kaup, 1829, Macroneomys Fejfar, 1966, Paenelimnoecus Baudelot, 1972 and Soricidae indeterminata. - Acta zoologica cracoviensia 34(2): $323-424$.

Rzebik-Kowalska B. 1995: Climate and history of European shrews (family Soricidae). - Acta zoologica cracoviensia 38(1): 95-107.

RZEBIK-Kowals KA B. 2000: Insectivora (Mammalia) from the Early and early Middle Pleistocene of Betfia in Romania. I. Soricidae Fischer von Waldheim, 1817. - Acta zoologica cracoviensia 43(1-2): $1-53$. 
Striczky L. \& Pazonyi P. 2014: Taxonomic study of the dormice (Gliridae, Mammalia) fauna from the late Early Pleistocene Somssich Hill 2 locality (Villány Hills, South Hungary) and its palaeoecological implications. - Fragmenta Palaeontologica Hungarica 31: 51-81. http://dx.doi.org/10.17111/FragmPalHung.2014.31.51

Tesakov A. S. 2004: Biostratigraphy of Middle Pliocene - Eopleistocene of Eastern Europe (based on small mammals). - Moscow, Nauka, 247 pp. [in Russian]

Ünay E., De Bruijn H. \& Suata-Alpaslan F. 2006: Rodents from the Upper Miocene Hominoid Locality Çorakyerler. - Beträge zur Paläontologie 30: 453-467.

WANG X. \& FLYNn L. J. 2013: Fossil Mammals of Asia: Neogene Biostratigraphy and Chronology. Columbia University Press, 732 pp. 